\title{
Topical Nano and Microemulsions for Skin Delivery
}

\author{
Christofori M. R. R. Nastiti ${ }^{1,2,+}$, Thellie Ponto ${ }^{1,+}{ }^{3}$ Eman Abd ${ }^{3}$, Jeffrey E. Grice ${ }^{3}$, \\ Heather A. E. Benson ${ }^{1}$ and Michael S. Roberts ${ }^{3,4, *}$ \\ 1 School of Pharmacy, Curtin Health Innovation Research Institute, Curtin University, G.P.O. Box U1987, \\ Perth, WA 6845, Australia; c.nastiti@postgrad.curtin.edu.au (C.M.R.R.N.); \\ thellie.ponto@postgrad.curtin.edu.au (T.P.); H.Benson@curtin.edu.au (H.A.E.B.) \\ 2 Faculty of Pharmacy, Sanata Dharma University, Yogyakarta 55282, Indonesia \\ 3 Therapeutics Research Centre, The University of Queensland Diamentina Institute, Faculty of Medicine, \\ Translational Research Institute, Woolloongabba, QLD 4102, Australia; e.abd@uq.edu.au (E.A.); \\ jeff.grice@uq.edu.au (J.E.G.) \\ 4 School of Pharmacy and Medical Sciences, University of South Australia, Adelaide, SA 5000, Australia \\ * Correspondence: m.roberts@uq.edu.au; Tel.: +61-7-34438031; Fax: +61-7-34437779 \\ + These authors contributed equally to this work.
}

Received: 11 August 2017; Accepted: 13 September 2017; Published: 21 September 2017

\begin{abstract}
Nanosystems such as microemulsions (ME) and nanoemulsions (NE) offer considerable opportunities for targeted drug delivery to and via the skin. ME and NE are stable colloidal systems composed of oil and water, stabilised by a mixture of surfactants and cosurfactants, that have received particular interest as topical skin delivery systems. There is considerable scope to manipulate the formulation components and characteristics to achieve optimal bioavailability and minimal skin irritancy. This includes the incorporation of established chemical penetration enhancers to fluidize the stratum corneum lipid bilayers, thus reducing the primary skin barrier and increasing permeation. This review discusses nanosystems with utility in skin delivery and focuses on the composition and characterization of ME and NE for topical and transdermal delivery. The mechanism of skin delivery across the stratum corneum and via hair follicles is reviewed with particular focus on the influence of formulation.
\end{abstract}

Keywords: microemulsion; nanoemulsion; transdermal; skin penetration; penetration enhancer; nanosystem

\section{Introduction}

The skin provides an effective barrier to protect the body from the penetration of molecules and micro-organisms in the external environment, and from excessive loss of water to maintain homeostasis. The main skin barrier resides in the stratum corneum (Figure 1) due to its unique structure of layers of flattened corneocytes surrounded by lipid bilayers composed primarily of ceramides [1]. Penetration of most topically applied compounds follows the tortuous route of the stratum corneum lipid bilayers (intercellular) [2], although the transcellular route through the corneocytes may contribute in some circumstances [3]. Although hair follicles (and associated sebaceous glands) and sweat glands account for only about $0.1 \%$ of the total skin surface area [4], these appendages are potential routes of access into the skin, and may be important for nanosystems.

Compounds that successfully diffuse across the stratum corneum are typically relatively small (up to about $500 \mathrm{Da}$ ), lipophilic ( $\log \mathrm{P} 1-3)$ and water soluble, thus excluding many potentially useful therapeutic compounds with properties that do not fit these criteria. A range of micro- and nanosystems has been investigated as potential delivery vehicles that could enhance the skin penetration of both small and macromolecules that do not otherwise permeate the stratum corneum in sufficient quantities to provide a therapeutic outcome. Here, we review micro and nanosystems that have been applied to 
skin delivery and focus particularly on micro- and nanoemulsions, as these present an extension of the most commonly applied topical formulations used in pharmaceutical, cosmeceutical and personal care products.

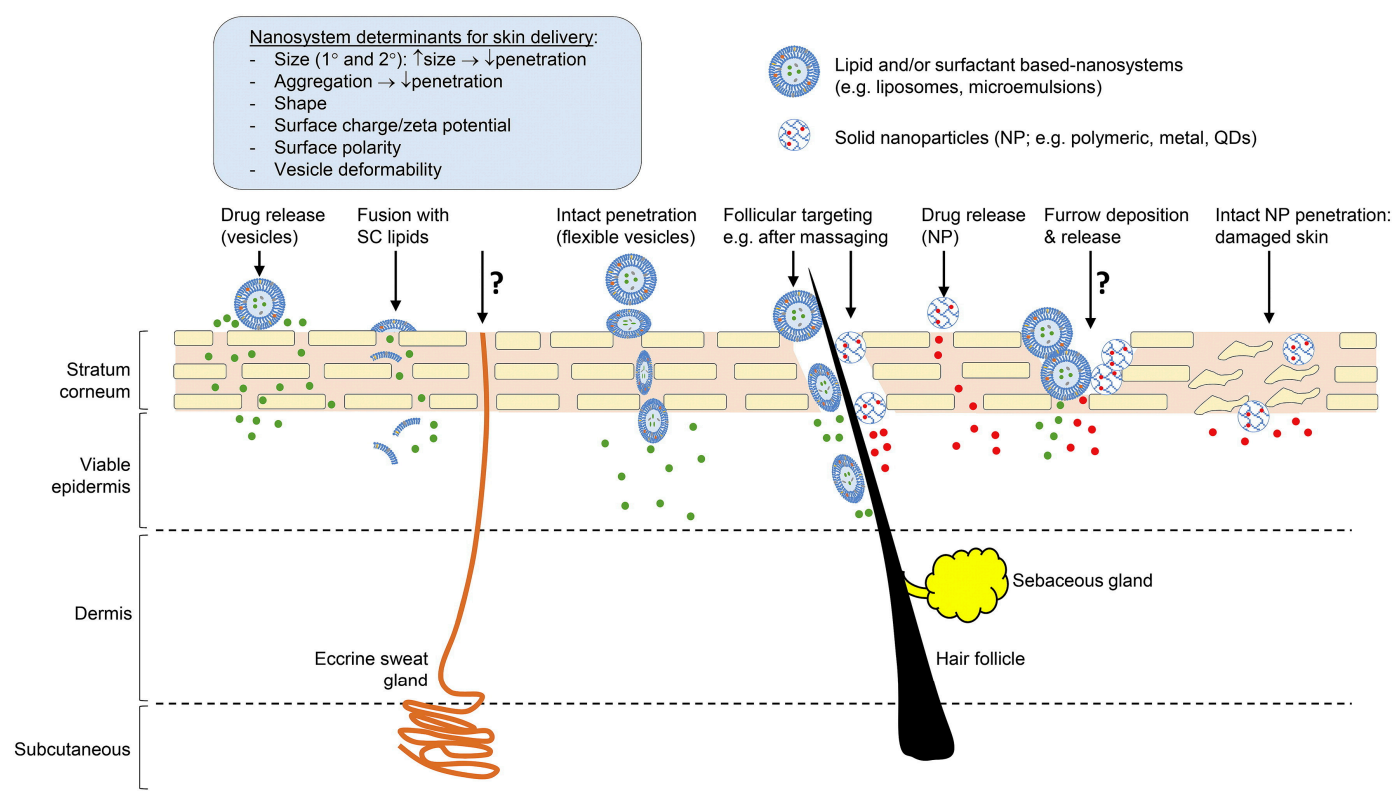

Figure 1. Properties of nanosystems determining skin absorption and potential routes of penetration (skin layer thicknesses not drawn to scale). Reproduced with permission from [5].

\section{Classification of Nano and Microsystems Used for Skin Delivery}

Nanosystems that have been investigated for enhanced skin permeation include microemulsions (ME), nanoemulsions (NE), nanoparticles of various compositions including solid lipid nanoparticles (SLN), nanostructured lipid carriers (NLC), liposomes and vesicles [5]. These nanosystems can offer significant advantages in the formulation of hydrophobic molecules, enhancing their solubility and thus bioavailability. This approach has been used to formulate hydrophobic actives for a range of routes of administration, including topical application to the skin. An example is Estrasorb ${ }^{\circledR}$ (Novavax Inc., Malvern, PA, USA), which contains oestradiol hemihydrate (logP 3.3) in a nanoemulsion composed of soybean oil, water, polysorbate 80 and ethanol, packed in single dose foil pouches for application to the legs in the management of vasomotor symptoms associated with menopause. Topicaine ${ }^{\circledR}$ (ESBA Laboratories Inc., Jupiter, FL, USA) is a microemulsion-based gel product (composed of jojoba oil, aloe vera oil, ethanol, benzyl alcohol, glycerine and water emulsified by glyceryl monostearate, and gelled with carbomer 940) containing lidocaine for localised pain relief. There are also examples of nanosystems designed to enhance delivery of hydrophilic compounds. Ameluz ${ }^{\circledR}$ topical gel (Biofrontera Pharma GmbH, Leverkusen, Germany) containing aminolevulinic acid (logP 1.5) in a nanoemulsion composed of soybean phosphatidylcholine, water, polysorbate, propylene glycol and isopropyl alcohol for the treatment of actinic keratosis and basal cell carcinoma. The range of nanosystems used for skin delivery is classified below. Figure 1 summarises the suggested and/or established mechanisms of skin permeation of nanosystems. While some routes are well described in the literature, the extent to which other routes, such as the eccrine sweat glands and via skin furrows (designated as ? in Figure 1), contribute to skin permeation is less well established. We have demonstrated that topically applied zinc oxide nanoparticles deposit in the skin furrows, but this does not contribute to permeation to deeper skin tissues [6,7]. 
Microemulsions (ME): transparent, monophasic, optically isotropic and thermodynamically stable colloidal dispersions composed of oil, water, surfactant and cosurfactant with droplet sizes in the range $10-100 \mathrm{~nm}[8]$.

Nanoemulsions (NE): transparent, monophasic, optically isotropic and kinetically stable colloidal dispersions composed of oil, water, surfactant and cosurfactant with droplet sizes less than $100 \mathrm{~nm}$.

Solid Nanoparticles: Discrete particles in the size range up to $1000 \mathrm{~nm}$ composed of inorganic materials such as metal oxides (e.g., zinc oxide, titanium dioxide) or polymers. There is a considerable body of evidence to show that these nanoparticles do not permeate human skin under a range of administration conditions [6,7]. Their primary application is as sunscreen products.

Solid Lipid Nanoparticles (SLN): composed of lipids that are solid at room temperature with a surface covering of surfactant to stabilise them as a nano-dispersion [9]. SLN enhance skin permeation by prolonging contact with the skin surface, providing an occlusive barrier that hydrates the skin, and interacting with the lipids in the stratum corneum bilayers. They are particularly useful for formulation of hydrophobic actives such as vitamin A, E and coenzyme Q in cosmetically elegant products, and maintaining the stability of compounds such as retinol that are prone to decomposition by light and oxygen [9].

Nanostructured lipid carriers (NLC): colloid systems composed of a fluid lipid phase embedded into a solid lipid matrix or localized at the surface of solid platelets and the surfactant layer $[9,10]$. The spatial structure of the lipids allows greater drug loading and better stability compared to SLN.

Liposomes: spherical vesicles composed of amphiphilic phospholipids and cholesterol, self-associated into multilamellar, large unilamellar and small unilamellar vesicles.

Flexible vesicles: composed of materials that will associate into bilayer structures but incorporate components that confer flexibility, thereby allowing the vesicles to deform in shape. Compositions that associate into flexible vesicles include ethosomes (phospholipids with a high proportion of ethanol) [11], niosomes (non-ionic surfactants) [12], invasomes (phospholipids, ethanol and a mixture of terpene penetration enhancers) [13], SECosomes (surfactant, ethanol and cholesterol) [14] and PEV (penetration enhancer vesicles, for which a range of penetration enhancers have been investigated including oleic acid, limonene, propylene glycol, Transcutol $\left.{ }^{\circledR}\right)[15,16]$. Multiple mechanisms are likely to contribute to enhanced skin permeation including the effect of the vesicle components on the stratum corneum lipids and the potential, as proposed by Cevc, that the vesicles have sufficient flexibility to squeeze through the stratum corneum intact $[17,18]$.

Polymeric micelles and dendrimers: nanosized, colloidal carriers with a hydrophilic exterior shell and a hydrophobic interior core, comprised of two main categories of hydrophobically assembled micelles and polyion-complex micelles [19]. Dendrimers are highly branched polymer structures incorporating drug and potentially, penetration enhancer molecules [20].

\section{Formulation of Micro and Nanoemulsions}

The focus of this review is the application of ME and NE in dermal and transdermal drug delivery. In comparison to many of the nanosystems outlined above, ME and NE offer advantages in terms of simplicity and stability. Coarse emulsions are composed of oil and water phases, with one dispersed as droplets in the other, and stabilised by a surfactant. In addition to their obvious droplet size difference, ME are clear/transparent, form spontaneously, have low interfacial energy and are thermodynamically stable, unlike emulsions that are cloudy, require energy in preparation, have high interfacial energy and are kinetically stable [21]. While the terminology suggests that NE would have a smaller particle size than $\mathrm{ME}$, based on nano and micro referring to $10^{-9}$ and $10^{-6}$ respectively, this is a quirk of the history of the development of colloidal dispersions, and the size range of NE and ME is similar. Essentially, the terms ME and NE entered widespread usage before they were properly defined or distinguished from each other [22]. Both NE and ME typically have low polydispersity (up to about $10 \%)$ compared to the much higher polydispersity exhibited by emulsions $(>40 \%)$. 
NE are thermodynamically unstable but kinetically stable, and can be prepared by both low and high energy methods. Given sufficient time, an NE will phase separate. Destabilization mechanisms include flocculation, coalescence, Ostwald ripening and creaming, with Ostwald ripening being the dominant mechanism of destabilization for NE [22-24]. The systems also differ when exposed to dilution and temperature fluctuations. ME are affected and potentially broken by temperature changes and/or dilution, whereas NE droplets will remain stable under these physical stresses [23]. Thus, the primary difference between NE and ME is their thermodynamic stability [22], which also results in the higher energy input required to form NE compared to ME. Detailed examination of the terminology, differences and similarities of NE and ME, with particular focus on their physical chemistry, is provided by McClements [22], Anton and Vandamme [23] and Gupta et al. [24]. The similarities and differences between emulsions, ME and NE are summarized in Table 1.

Table 1. Comparison of the properties of emulsions, microemulsions and nanoemulsions.

\begin{tabular}{cccc}
\hline & Emulsion & Microemulsion & Nanoemulsion \\
\hline Physical description & Coarse dispersion & Colloidal dispersion & Colloidal dispersion \\
Particle size range & $>500 \mathrm{~nm}$ & $<100 \mathrm{~nm}$ & $<100 \mathrm{~nm}$ \\
Polydispersity & High & Low & Low \\
Thermodynamic stability & Unstable & Stable & Unstable \\
Preparation & High energy & Low energy & Low /high energy \\
Composition: surfactant to oil ratio & Low & High & Moderate \\
Physical appearance & Creamy & Transparent & Transparent \\
Texture & Semi-solid & Fluid & Fluid \\
\hline
\end{tabular}

The low interfacial tension and small particle size in ME and NE is due to their composition; in particular, the presence of cosurfactants such as short or medium chain alcohols or polyglyceryl derivatives working in combination with the primary surfactant [25]. The surfactant to oil ratio is much higher in ME (see examples in Table 2) than in coarse emulsions (typically 2-10\%). While coarse emulsions are creamy in appearance and tend to adhere well to the skin, NE and ME are more fluid. To achieve an appropriate consistency of ME or NE on the skin, a viscosity enhancing polymer is added to form a gel.

In general, non-ionic surfactants are favoured as they are less irritating to human skin. A wide range of non-ionic surfactants and the amphiphilic surfactant lecithin have been investigated, together with a variety of oils and cosurfactants (Table 2). The development of NE and ME formulations is based on ternary diagrams to determine the optimal component ratios.

\section{Formulation Parameters: Composition and Preparation Methods}

ME can be formed spontaneously at optimal component ratios and temperature, although in practice, low energy such as heat or stirring is generally applied to facilitate formation. ME and NE are classified as water in oil $(\mathrm{w} / \mathrm{o})$ or oil in water $(\mathrm{o} / \mathrm{w})$, each designating the dispersed phase within the continuous phase. Some more complex systems also exist such as o/w/o and w/o/w. Bicontinuous $\mathrm{ME}$ in which the aqueous and oil phases are intertwined and stabilized by sheet-like surfactant areas in the areas between the phases [26] can also exist. Lindman et al. [27] demonstrated that continuous pathways can exist between interconnected-sphere structures, lamellar-like structures, tubule structures and other structures in ME systems. Bicontinuous structures are dynamic and are characterized by a higher amphiphilic character, greater fluctuation at the interface, lower interfacial tension and better solubilizing properties compared to globular w/o or o/w ME [28,29]. Naoui et al. [29] compared the penetration of the hydrophilic drug caffeine across excised pig skin, when applied in o/w, w/o and bicontinuous ME having the same ingredients. Transdermal flux of caffeine was in the order $\mathrm{w} / \mathrm{o}<$ bicontinuous < o/w ME, with the o/w ME providing permeation of $50 \%$ of the applied dose within $24 \mathrm{~h}$. In contrast, Bhatia et al. [28] reported that, for the lipophilic drug adapalene, the penetration in hair follicles increased by almost three times as the microstructure of the applied 
ME shifted from o/w to bicontinuous, with an increase in water content of the ME. In both cases, presentation of the drug in the continuous phase of the ME provided the greatest drug delivery, with the bicontinuous system acting as an intermediate system.

\subsection{Preparation Methods}

NE formation is generally a two-step process with the initial preparation of a macroemulsion that is then converted to a NE. This requires external energy applied by high-energy (HEE) or low-energy (LEE) methods (Figure 2). HEE methods such as high-pressure homogenizers, microfluidizers and ultrasonicators generate highly disruptive forces that break down the oil and water phases, causing them to intersperse and form nanometer-sized droplets. LEE methods include heat, stirring and phase inversion. Control of NE droplet size is related to both the preparation method and the formulation components.

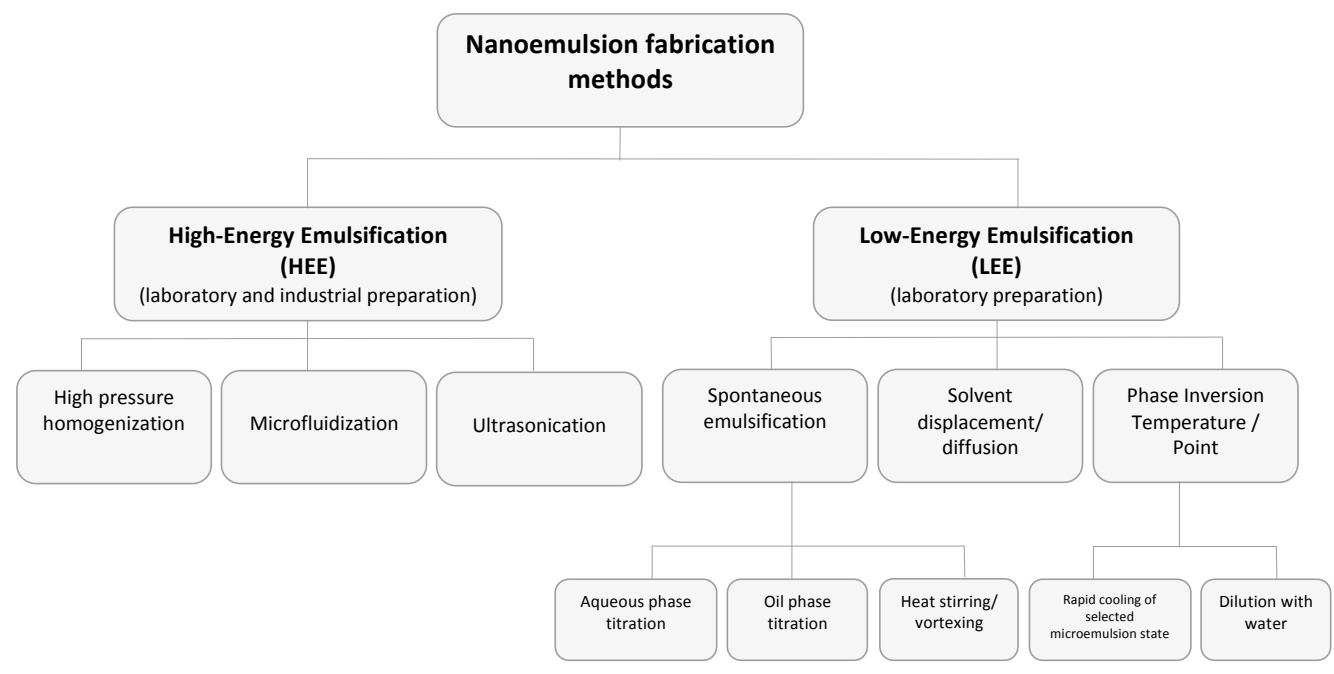

Figure 2. Schematic representation of nanoemulsion preparation methods adapted from [30,31].

Dilution can be used as a method of forming a final ME or NE product. NE can be prepared by diluting $\mathrm{o} / \mathrm{w}$ microemulsions, bicontinuous microemulsions, or w/o ME with water [32]. Dilution of an $\mathrm{o} / \mathrm{w} \mathrm{ME}$ with water induces a proportion of the surfactants to dissolve into the aqueous phase. The surfactant molecules remaining at the oil/water interface cannot maintain the low interfacial tension required for thermodynamic stability and the ME droplets give rise to nanoemulsion droplets [33].

When diluting bicontinuous $\mathrm{ME}$, the homogeneous nucleation that occurs during the spontaneous emulsification process leads to the formation of NE [34] Despite this mechanism, NE may be formed by the migration of surfactants or cosurfactants through the oil-water interface due to the "ouzo effect" when diluting bicontinuous ME or w/o ME [35]. When diluting w/o ME, the oil may act as nuclei, leading to heterogeneous nucleation, resulting in droplets with larger sizes and polydispersity [36]. NE formed by diluting o/w ME or bicontinuous ME are more stable and have smaller droplets [37].

Sole et al. [32] reported that NE with droplet diameters of $20 \mathrm{~nm}$ were obtained when diluting $\mathrm{o} / \mathrm{w}$ ME regardless of the ME composition or dilution procedure (incremental or all at once). In contrast, when the starting emulsion was a w/o ME, NE were only obtained if the emulsification conditions allowed the establishment of an equilibrium in an $\mathrm{o} / \mathrm{w}$ ME domain during the process. These conditions required the stepwise addition of water and w/o ME with specific oil to surfactant ratios. 


\subsection{Composition}

The choice of emulsion components and ratios of these components is critical in generating stable emulsion systems with appropriate particle sizes. A wide range of components and combinations has been investigated (Table 2).

Oil phase components include fatty acids (e.g., oleic acid), esters of fatty acids and alcohols (e.g., isopropyl myristate, isopropyl palmitate, ethyl oleate), medium chain triglycerides, triacetin, terpenes (e.g., limonene, menthol, cineole) and other penetration enhancers. These may be used alone or in combination to form the oil phase. The aqueous phase may include sodium chloride and buffer salts, preservatives and penetration enhancers. Viscosity enhancing agents (e.g., Carbopol ${ }^{\circledR}$, Aerosil ${ }^{\circledR}$, gelatin) are incorporated to reduce the fluidity and generate the desired final consistency of the product.

A wide range of materials has been used as surfactants and cosurfactants (see examples in Table 2). Consideration must be given to combinations that effectively reduce interfacial tension and produce stable emulsions with appropriate particle size, but which also ensure minimal skin irritancy; thus, the preference for non-ionic surfactants. Commonly used surfactants include Tween ${ }^{\circledR}$ (polysorbates), Cremophor ${ }^{\circledR}$ (mixture of macrogol glycerol hydroxystearate, PEG-40 castor oil, polyoxyl 40 hydrogenated castor oil), Transcutol ${ }^{\circledR} \mathrm{P}$ (diethylene glycol monoethyl ether), Plurol Oleique $^{\circledR}$ (polyglyceryl-3-oleate), Plurol Isostearique ${ }^{\circledR}$ (isostearic acid ester of poly-glycerols and higher oligomers) and Labrasol ${ }^{\circledR}$ (mixture of mono-, di- and tri-glycerides of C8 and C10 fatty acids, and mono- and di-esters of PEG) [38]. Lecithin, an amphiphilic compound, has been widely investigated as the "ideal" surfactant because it is a natural compound with a low skin irritancy profile. Organogels are $\mathrm{w} / \mathrm{o}$ ME based on lecithin and an apolar organic solvent, that form gel-like reverse micellar systems with high viscosity, solubilisation capacity and thermodynamic stability, and are transparent and biocompatible [39]. Cosurfactants are generally short and medium chain alcohols and polyglyceryl derivatives, including ethanol, isopropanol, isopropyl myristate and propylene glycol (PG). Nonionic surfactants have also been used to provide low irritancy cosurfactants [38,40]. Table 2 shows examples of the range of $\mathrm{NE}$ and $\mathrm{ME}$ compositions and their skin delivery. Lopes provides an excellent review focused on the formulation and physical characterisation of ME [41].

\section{Physical Characterisation of Nano- and Microemulsions}

\subsection{Pseudo Ternary Phase Diagrams}

$\mathrm{NE}$ and ME are characterised by a range of physical properties that are important determinants of their structure, drug release and stability. Pseudo ternary phase diagrams are often constructed to indicate the boundaries of the different phases as a function of the composition of the aqueous, oil and surfactant/cosurfactant components [21,42]. Mixtures of the oil, surfactant and cosurfactant at certain weight ratios at ambient temperature $\left(25^{\circ} \mathrm{C}\right)$ are diluted with the aqueous solution under moderate agitation. After equilibrium, the combinations of the three components that give rise to clear emulsions, shown by visual inspection or polarised light microscopy, are mapped on the phase diagram. Examples of pseudo-ternary phase diagrams showing regions of various phases for mixtures of oil and water and different ratios of surfactant and cosurfactant (Tween 80 and Brij 52) are shown in Figure 3 [43].

\subsection{Particle Size, Polydispersity and Zeta Potential}

Particle/droplet size and polydispersity index can be determined by microscopic and scattering techniques. Dynamic light scattering, also called photon correlation spectroscopy (PCS), is used to analyse the fluctuations in intensity of incident laser light as it passes through droplets or particles that are subject to Brownian motion. A number of instruments are available that can provide rapid analysis of the particle/droplet size (down to about $1 \mathrm{~nm}$ ), polydispersity (a measure of the broadness 
of the size distribution derived from the cumulative analysis of dynamic light scattering: indicates the quality or homogeneity of the dispersion) and zeta potential (surface charge).

Freeze fracture transmission electron microscopy (TEM) and cryo-TEM allow the direct imaging of nanostructures at high resolution [44]. Laser light scattering, photon correlation spectroscopy (PCS), small angle X-ray scattering (SAXS), small angle neutron scattering (SANS) are useful for determining particle size distribution [45]. Consideration of particle interactions within the emulsion systems, and understanding the limitations of these techniques, is critical to ensure accurate measurements [21].
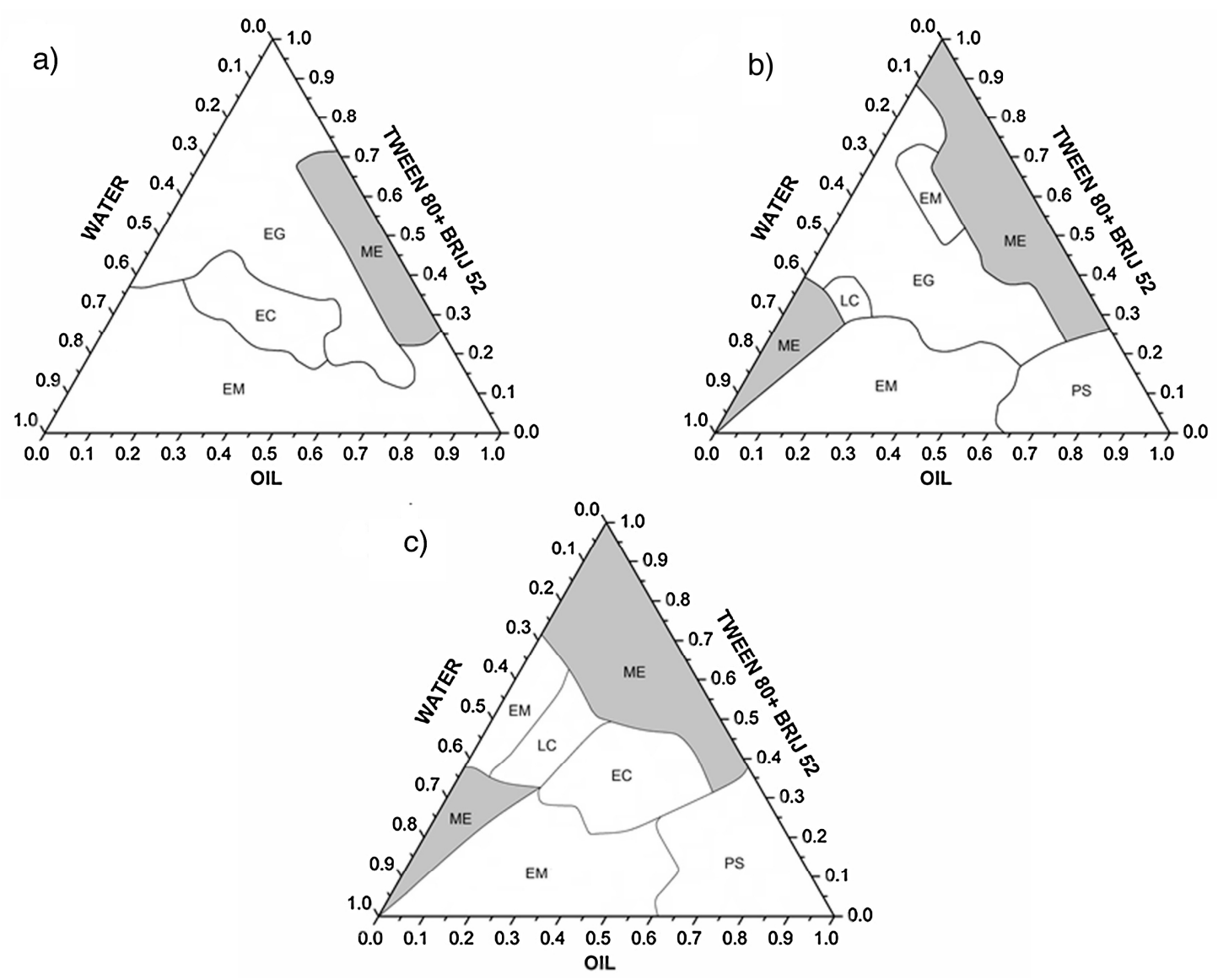

Figure 3. Pseudo-ternary phase diagrams formed by a mixture of caprylic/capric triglycerides as the oil phase, Tween 80: Brij 52 at 7:3 (a), 8:2 (b) and 9:1 (c) surfactant mix-ratio and water. Gray area represents the microemulsion systems (ME). Liquid crystal (LC), emulsion (EM), emollient gel (EG), emollient cream (EC), phase separation (PS). Reproduced with permission from [43].

\subsection{Viscosity and Electrical Conductivity}

Viscosity and conductivity measurements provide information on the emulsion structure and can be used to detect phase inversion phenomena [45]. High conductivity values demonstrate a water continuous phase, whilst an oil continuous phase will have low or no conductivity. Where the conductivity increases this may demonstrate the percolation effect caused by the attractive interactions between water droplets, that is characteristic of a bicontinuous structure [46,47]. These measurements can also be useful in predicting drug release from the NE or ME.

Electrical conductivity meaurements are simple and inexpensive, involving the insertion of conductometer electodes into the NE/ME formulation. High conductivity is obtained for an aqueous continuous phase, and phase inversion in response to formulation or temperature change can be monitored by the change in electrical conductivity. The technique is therefore useful for determining emulsion type, and monitoring changes during preparation or storage [48]. 
Viscosity is an important property that influences the stability and drug release of NE and ME formulations. The viscosity of an emulsion is a function of the surfactant, water and oil components and their concentrations. An increase in the water content will lead to a lowering of the viscosity, while decreasing the surfactant and co surfactant content increases interfacial tension between the water and oil, causing increased viscosity. Monitoring of viscosity changes is a method of assessing the stability of liquid and semi-solid preparations, including nanoemulsion formulations [49]. In general, cone and plate type rheometers are used for rheological evaluation of NE and ME [50].

Podlogar et al. [45] provide an excellent example of how the data from a range of these techniques can be collectively interpreted to provide the structural characterisation of ME. They found good agreement in their measurements of density and surface tension, and by viscometry, conductivity, DSC and SAXS techniques, for their ME (composed of IPM and water with Tween $40^{\circledR}$ and Imwitor $308^{\circledR}$ [glyceryl caprylate] surfactant/cosurfactant mix). The SAXS data showed a monodisperse w/o ME with strong attractive interactions. The type of ME was confirmed by DSC by demonstrating the degree of interaction between water and surfactants. Conductivity, viscosity, density and surface tension measurements confirmed a percolation transition to a bicontinuous structure. The authors concluded that these techniques could be applied to determine the type and structure of more complex systems, and could enable partitioning and release rates of drugs from ME to be predicted.

\section{Skin Delivery from Nano and Microemulsions}

$\mathrm{NE}$ and ME systems have been developed for the delivery of a wide range of compounds to the skin for dermatological, cosmetic/cosmeceutical and transdermal outcomes. Enhanced skin delivery has been demonstrated in comparison to conventional emulsions and gels. This has been attributed both to the action of their components on the skin and their phase structure and particle size. We have evaluated the literature on in vitro and in vivo studies of skin permeation of compounds applied as $\mathrm{NE}$ and ME systems, with particular focus on the formulation composition and properties, and skin permeation experimental design. The choice of appropriate models for skin permeation evaluation is critical to the accurate assessment of the potential of these systems as future therapeutic products. Ideally, studies are conducted on human excised skin or volunteers, although pig and piglet skin does provide a reasonable surrogate. In studies of follicular penetration, Lademann has suggested that pig ear skin is a superior in vitro model, as it does not contract and close the follicle openings, as excised human skin does [51]. Animal models such as rat, mouse and rabbit have a weaker barrier than human skin and their use tends to over-estimate skin permeation relative to humans. In addition, experimental parameters such as the appropriate choice of receptor solutions that do not damage skin membranes, while providing sufficient receptor phase solubility to achieve sink conditions and suitable hydrodynamics to limit the formation of aqueous diffusion layers [52] need to be scrutinized, along with validated analytical methods and application protocols. In some cases high proportions of alcohols [53-57] or other known penetration enhancers such as DMSO [58] have been used to provide sink conditions in the receptor phase, with the potential to compromise the skin barrier and lead to over-estimation of drug flux. Our work has also shown that even when non-sink conditions are used in in vitro permeation experiments, the results can be corrected to derive the equivalent sink condition data, provided the effects of aqueous diffusion layers are minimised [52].

Given the presence of sebum in hair follicles it is likely that oil, surfactant and alcohol based vehicles such as NE/ME could facilitate transfollicular transport of both hydrophilic and lipophilic compounds. Bhatia et al. [28] indicated that ME not only increased the permeation of adapalene in the stratum corneum, but also demonstrated optimal penetration into the hair follicles. The permeation of adapalene in the stratum corneum increased from 1.40 to $3.37 \mu \mathrm{g}$ and penetration in the hair follicles increased significantly from 0.017 to $0.292 \mu \mathrm{g}$ in ME treated skin compared with the control. This represents a 17 -fold increase in penetration in the hair follicles compared with the control. Teichmann et al. [59] compared the skin penetration of the lipophilic dye curcumin incorporated in an $\mathrm{o} / \mathrm{w} \mathrm{ME}$ and a coarse emulsion/cream applied to human volunteers. Using the method of tape 
stripping to remove the stratum corneum (SC), the depth profiles of the dye within the horny layer were compared. The depth of penetration, determined both by tape stripping and laser scanning microscopy, was greater with the ME than the cream. In addition, when applied in the ME, curcumin penetrated into the complete follicular infundibula, whereas with the cream a fluorescence signal was only received from the follicular orifices.

While some hair follicles are open, others are plugged with shed corneocytes and dry sebum [60], which can particularly restrict the permeation of hydrophilic compounds. Hair follicles can be opened by a mechanical peeling technique applied prior to the administration of a topical formulation [61]. We investigated the follicular delivery of the hydrophilic compound caffeine from NE composed of penetration enhancer chemicals (unpublished data). We found that when we open the hair follicles, the increase in caffeine permeation relative to control (aqueous solution) was greater for oleic acid and eucalyptol NE. The cumulative amount and flux of caffeine increased by 27 - and 23-fold with oleic acid NE relative to control. Eucalyptol NE increased the cumulative amount of caffeine penetrated by 43-fold and flux by 31-fold compared to control.

In the following section, we discuss representative literature on a range of formulations, focused on the anti-inflammatory drug class. Examples of NE formulations evaluated for a broad range of therapeutic classes relevant to topical and transdermal delivery are also summarised in Table 2.

\section{Anti-Inflammatory Drugs}

Non-steroidal anti-inflammatory drugs (NSAIDs) are widely used in the management of musculoskeletal and arthritic pain. These drugs often create gastro-intestinal side effects when taken orally, thus application to the skin over the painful site is an attractive alternative. A number of NSAIDs have been available as gel and cream formulations for many years. There is extensive literature focused on the development and evaluation of ME and NE systems for topical delivery of a number of NSAIDs including diclofenac [62,63], aceclofenac [57,64,65], piroxicam [66], indomethacin [67-69], ibuprofen, celecoxib [70,71], etoricoxib [72], naproxen [73], flufenamic acid [50,74,75], ketoprofen [39,76,77], flurbiprofen [78], lornoxicam [79], and meloxicam [80]. Consequently, we have focused our discussion on this drug class to illustrate the development and potential of ME/NE formulations for topical and transdermal delivery.

ME composed of oleic acid as the internal phase, Labrasol ${ }^{\circledR} /$ Cremophor $^{\circledR} \mathrm{RH}$ as the cosolvent mixture and water were shown to enhance skin permeation of the lipophilic NSAID ketoprofen [76]. Increasing the water content (from 5 to $64 \%$ ) and reducing the surfactant content (from 80 to $30 \%$ ) increased ketoprofen skin permeation. This increased permeation is achieved by reducing the solubility of the drug and hence increasing its thermodynamic activity in the external phase, and has been reported for other lipophilic compounds [74,81]. Hoppel et al. [74] evaluated a lecithin related, naturally derived monoacyl phosphatidycholine (MAPL) surfactant, with the aim of reducing the irritancy associated with many conventional ionic surfactants. The in vitro skin permeation of flufenamic acid across dermatomed porcine skin was evaluated from ME composed of oleic acid, water, MAPL and isopropanol as co-surfactant. Attenuated total reflectance-fourier transform infrared spectrometry (ATR-FTIR) analysis and tape stripping of the stratum corneum demonstrated that the MAPL itself did not penetrate beyond the superficial layers of the stratum corneum. This superficial penetration is likely to minimise irritancy. NSAID skin permeation was significantly greater for the water-rich ME than other ME compositions and a commercial flufenamic acid product. When applied to the skin the isopropanol evaporated, leaving crystal-like structures of MAPL on the skin surface and forming a barrier to skin permeation. However, the ME with high water content prevented the formation of these MAPL structures. In a subsequent study exploring the influence of MAPL content it was confirmed that higher MAPL content resulted in lower skin permeation of flufenamic acid, most likely due to the MAPL acting as a hydrophilic barrier to the permeation of the lipophilic drug [50].

Duangjit et al. [82] applied a simple lattice statistical design approach to provide a more rational choice of ME composition. The physical properties (size, charge, conductivity, $\mathrm{pH}$, viscosity, 
drug content and loading capacity) and skin permeation were determined for ketoprofen-loaded ME composed of oleic acid, Cremophor ${ }^{\circledR} \mathrm{RH}$, ethanol and water. The authors reported that the experimentally determined skin permeation correlated well with their predictions using Design-Expert ${ }^{\circledR}$ software (Stat-ease, Minneapolis, MN, USA), and allowed optimisation of skin delivery via rational design.

Oleic acid-based ME have also been investigated for skin delivery of flufenamic acid $[74,75,83]$. Mahrhauser et al. [75] combined a fluorosurfactant (Hexafor ${ }^{\mathrm{TM}} 670$ or Chemguard S-550-100) with isopropyl alcohol as cosurfactant (total $\mathrm{S}+\operatorname{CoS} 65 \% w / w$ ) to form an anisotropic ME with oleic acid $(10 \% w / w)$ and water $(25 \% w / w)$, loaded with flurbiprofen. Physical characterisation using conductivity, SAXS and NMR showed that the ME was oil in water with spherical or rod-shaped microstructures. In vitro porcine skin penetration demonstrated enhanced permeation for the ME with elongated rather than spherical microstructures, suggesting that the shape of the ME particles is an important determinant in skin delivery. In a parallel study incorporating diclofenac sodium in the $\mathrm{ME}$, increased deposition into the stratum corneum of porcine ear skin was demonstrated by tape stripping [83]. ATR-FTIR studies showed significant shifts of the $\mathrm{CH}_{2}$ stretching absorbance when the ME was applied to the skin, demonstrating increased disorder of the stratum corneum lipids that was indicative of reduced barrier function. Similar shifts were not seen when pure fluorosurfactant was applied, suggesting that the permeation enhancement was a feature of the ME and not simply the surfactant constituent.

Sugar-based esters have been investigated as another source of low irritancy surfactants [84]. Sucrose esters [laurate (SL) or myristate (SM)] were shown to be superior surfactants to Tween ${ }^{\circledR} 80$ (T80) for the delivery of aceclofenac from ME composed of isopropyl myristate, water and co-surfactant of isopropyl alcohol or Transcutol ${ }^{\circledR} \mathrm{P}$. Aceclofenac release from the ME was determined across cellulose membranes and in vivo tape stripping (12 strips) was performed on human volunteers. An in vivo pharmacokinetic study was conducted in rats and skin irritancy of blank ME determined on human volunteers by measuring trans epidermal water loss (TEWL), erythema and hydration. The ME incorporating sugar esters released significantly more aceclofenac over $6 \mathrm{~h}$ than Tween 80-based ME ( $87.28 \pm 4.89$ and $70.66 \pm 4.46$ compared to $53.65 \pm 5.62 \%$ for SL, SM and T80 respectively). Aceclofenac penetration into the stratum corneum (by tape stripping) from the sugar ester ME was approximately two times that of the T80 ME $\left(60.81 \pm 5.97,60.86 \pm 3.67,27.00 \pm 5.09 \mathrm{mg} / \mathrm{cm}^{2}\right.$ for SL, SM, T80 respectively), and this was reflected in the maximum plasma concentrations and lag times measured in the rats $(275.57 \pm 109.49,281.32 \pm 6.76,150.23 \pm 69.74 \mathrm{ng} / \mathrm{mL}$ and $0.44 \pm 0.19,0.74 \pm 0.32,2.41 \pm 2.70 \mathrm{~h}$ for SL, SM, T80 respectively). Not only were the sugar ester-based ME effective in the transdermal delivery of aceclofenac, but they also showed better skin tolerability [84].

Kriwet and Müller-Goyman [85] explored the mechanism of lecithin-based permeation enhancement by altering the ratio of diclofenac diethylamine, lecithin (soybean phosphatidylcholine) and water to develop a range of colloidal structures including ME, liposomes and lamellar liquid crystals. As diclofenac diethylamine is an amphiphilic molecule it interacts with the colloidal microstructure. At lecithin concentrations below $6 \%$ low viscosity ME were formed which gave rapid release of diclofenac diethylamine across a silicone impregnated dialysis membrane. Increasing the lecithin concentration led to phase transition into isotropic gels containing droplets with few lamellar layers surrounding the droplets. The increased viscosity of these systems resulted in decreased drug release. ME also gave higher permeation of diclofenac across human stratum corneum membranes than the other formulations tested, including a simple aqueous solution. The authors suggested that the increased permeation resulted from interaction between the lecithin phospholipids and the stratum corneum lipid bilayers, but this occurred only when presented as a ME and not as gel or liposomal formulations. In the liposomal formulations, the drug and phospholipids are too tightly held within the colloidal microstructure to effectively interact with the stratum corneum [85]. Further investigation of the interaction of lecithin-based ME and the stratum corneum was undertaken using FTIR and differential scanning calorimetry (DSC) [86]. In this case they used isopropyl palmitate as the oil phase 
(alone and in the lecithin-based ME) and investigated the in vitro permeation of indomethacin and diclofenac across full-thickness human skin and the interactions on isolated stratum corneum sheets. ME formulations provided much higher permeation compared to isopropyl palmitate solutions, for both drugs. ME and isopropyl palmitate alone gave similar temperature shifts of the stratum corneum lipid transitions so they could not distinguish the penetration enhancement role of lecithin.

Viscosity enhancing agents are often added to convert the ME into a gel consistency suitable for retention on the skin surface. Naeem et al. [87] compared gels composed of Carbopol ${ }^{\circledR} 934 \mathrm{P}$ and Xanthan gum bases containing ME (5\% $w / w$ oleic acid, 46\% $w / w$ Tween ${ }^{\circledR} 20$ :ethanol 2:1, 44\% $w / w$ water) or hydroalcoholic solution (ethanol/water) incorporating $5 \% w / w$ flurbiprofen. The transdermal flux of flurbiprofen across excised rabbit skin was $18.75 \pm 0.08,15.72 \pm 0.05,9.80 \pm 0.09$, $4.76 \pm 0.07$ and $2.70 \pm 0.05 \mu \mathrm{g} / \mathrm{cm}^{2} / \mathrm{h}$ over $24 \mathrm{~h}$ for the un-gelled ME, ME gelled with Carbopol and Xanthan, and hydroalcoholic solution gelled with Carbopol and Xanthan respectively. This clearly demonstrates that the ME delivers more NSAID than the hydroalcoholic solutions and that addition of a gelling agent reduces transdermal delivery. Similar findings were reported for lornoxicam [79] and aceclofenac [57], although it is interesting to note that this group have reported identical transdermal flux values for the two NSAIDs in these separately published manuscripts, despite the different drugs, compositions and experimental models. Shakeel et al. [67] also reported lower transdermal flux of indomethacin across rat skin from ME composed of 5\% Labrafil ${ }^{\circledR}, 50 \%$ water and $45 \%$ of a 3:1 ratio of Tween ${ }^{\circledR} 80$ and Transcutol ${ }^{\circledR}$, when gelled with $1 \%$ Carbopol $^{\circledR} 940(73.96 \pm 2.89$ and $61.64 \pm 2.38 \mu \mathrm{g} / \mathrm{cm}^{2} / \mathrm{h}$ ). It should be noted that there are other reports in which the addition of gelling agent did not significantly change the skin delivery (e.g., diclofenac diethylamine [63]) or indeed resulted in an increase in transdermal flux (e.g., amphotericin [58]).

The incorporation of additional chemical penetration enhancers [dimethyl sulfoxide (DMSO) and propylene glycol (PG)] in w/o ME compositions has been shown to further increase skin permeation across excised rabbit skin [88]. The relative effects of DMSO and PG were shown to be dependent on the cosurfactant in the ME formulation. PG gave better skin permeation of diclofenac sodium than DMSO when incorporated into isopropyl alcohol ME, whereas DMSO was superior to PG in propanol ME. Overall the ME containing isopropyl alcohol and PG gave greatest enhancement, although all ME formulations provided higher skin permeation of diclofenac than the commercial products tested.

We examined the skin permeation enhancement of the lipophilic NSAID naproxen and the hydrophilic drug caffeine applied in NE incorporating skin penetration enhancers oleic acid or eucalyptol as oil phases, with Volpo-N10 (an ethoxylated fatty alcohol) and ethanol as the surfactant and cosurfactant in a 1:1 ratio [73]. Caffeine and naproxen fluxes across human epidermal membranes were determined over $8 \mathrm{~h}$. All NE formulations significantly enhanced the skin penetration of both caffeine and naproxen, compared to aqueous control solutions. Caffeine maximum flux enhancement was associated with a synergistic increase in both caffeine stratum corneum solubility and skin diffusivity, whereas a formulation-increased solubility in the stratum corneum was the dominant mechanism for increased naproxen fluxes. Enhancements in stratum corneum solubility were related to the uptake into the stratum corneum of the formulation excipients containing the active compounds. We concluded that enhanced skin penetration from NE is primarily due to uptake of formulation excipients containing the active compounds into the stratum corneum with consequent impacts on stratum corneum solubility and diffusivity.

A number of in vivo pharmacokinetic studies have supported the enhanced skin delivery effects of $\mathrm{ME}$ demonstrated in vitro. For example, an eight-fold higher permeation of diclofenac from $\mathrm{ME}$ (w/o; 2:3 PEG-40 stearate/glyceryl oleate as surfactant mix, tetraglycol as cosurfactant, S/CoS ratio 8:1, isopropyl myristate as oil phase and water than Voltaren ${ }^{\circledR}$ Emulgel (commercial coarse emulsion gel product) was demonstrated in a rat pharmacokinetic study [89]. Constant plasma diclofenac levels of $0.7-0.9 \mu \mathrm{g} / \mathrm{mL}$ were maintained for at least $8 \mathrm{~h}$ following ME administration. In contrast, a subcutaneous injection of diclofenac solution $(3.5 \mathrm{mg} / \mathrm{kg})$ resulted in a peak plasma level of $0.94 \mu \mathrm{g} / \mathrm{mL}$ at $1 \mathrm{~h}$, which decreased rapidly to $0.19 \mu \mathrm{g} / \mathrm{mL}$ by $6 \mathrm{~h}$. 
Table 2. Examples of nanoemulsion (NE) formulations evaluated for topical and transdermal delivery: hydrophilic (H) and lipophilic (L) nature of active compound, composition (detail where available), preparation method and physical characterisation of emulsion formulation, and skin permeation experimental details and data.

\begin{tabular}{|c|c|c|c|c|c|c|c|c|c|c|}
\hline \multirow{2}{*}{$\begin{array}{l}\text { Therapeutic Class } \\
\text { and Active } \\
\text { Compound }\end{array}$} & \multirow{2}{*}{$H / L$} & \multirow{2}{*}{ Composition } & \multirow{2}{*}{$\begin{array}{l}\text { Preparation } \\
\text { Method }\end{array}$} & \multicolumn{4}{|c|}{ Physical Characterisation } & \multirow{2}{*}{\multicolumn{2}{|c|}{ Skin Permeation Evaluation }} & \multirow{2}{*}{ Ref } \\
\hline & & & & $\begin{array}{l}\text { Particle Size } \\
\quad(\mathrm{nm})\end{array}$ & $\begin{array}{c}\text { Surface } \\
\text { Charge }(\mathrm{mV})\end{array}$ & $\begin{array}{c}\text { Poly } \\
\text { Dispersity }\end{array}$ & $\begin{array}{l}\text { Viscosity } \\
\text { (mPa s) }\end{array}$ & & & \\
\hline \multicolumn{11}{|c|}{ NON-STEROIDAL ANTI-INFLAMMATORY DRUGS (NSAID) } \\
\hline \multirow[t]{2}{*}{ Aceclofenac } & \multirow[t]{2}{*}{$\mathrm{L}$} & \multirow{2}{*}{$\begin{array}{l}\text { Nanoemulsion NE31 (O/W) } \\
\text { Triacetin } 13.6 \% \\
\text { Water } 54.6 \% \\
\text { Cremophor EL }{ }^{\circledR} 23.9 \% \\
\text { PEG-400 7.9\% } \\
\text { Nanoemulsion gel NG31 } \\
\text { NE31 gelled with Carbopol } 934^{\circledR} 1 \% \\
\text { Drug load (DL): } 1.5 \mathrm{mg} \%\end{array}$} & \multirow{2}{*}{$\begin{array}{l}\text { Spontaneous } \\
\text { aqueous phase } \\
\text { titration }\end{array}$} & \multirow[t]{2}{*}{$\begin{array}{l}\text { NE31 } \\
39.48\end{array}$} & & \multirow[t]{2}{*}{$\begin{array}{l}\text { NE31 } \\
0.230\end{array}$} & \multirow[t]{2}{*}{$\begin{array}{l}\text { NE31 } \\
339.51 \pm 0.31\end{array}$} & Method (M) & $\begin{array}{l}\text { Full thickness rat abdominal skin } \\
\text { Receptor: methanol-PBS (pH 7.4) } \\
(3: 7)\end{array}$ & \multirow[t]{2}{*}{57} \\
\hline & & & & & & & & Results (R) & $\begin{array}{l}\text { Flux } J\left(\mu g \cdot \mathrm{cm}^{-2} \cdot h^{-1}\right) \text { in } 24 \mathrm{~h} \\
\text { NE31: } 254.90 \pm 1.25 \\
\text { NG31: } 199.60 \pm 6.93 \\
\text { Control }\left(\mathrm{Hiffenac}^{\mathrm{TM}} \mathrm{Gel}\right) \\
43.67 \pm 2.11 \\
\text { Enhancement ratio (ER) } \\
\text { NE31: } 5.84 \\
\text { NG31: } 4.57\end{array}$ & \\
\hline \multirow[t]{2}{*}{ Aceclofenac (ACF) } & \multirow[t]{2}{*}{$\mathrm{L}$} & \multirow{2}{*}{$\begin{array}{l}\text { Nanoemulsion } \mathrm{L}_{1.5} \mathrm{~S}_{0.5} \mathrm{P}_{2} \mathrm{~A} \\
\text { Medium chain triglycerides (MCT) } \\
\text { Castor oil 1:1 } 20 \% \\
\text { Water 76\% } \\
\text { Lecithin } 801.5 \% \\
\text { Sucrose stearate } \mathrm{S}-9700.5 \% \\
\text { Sucrose palmitate } \mathrm{P}-1670 \% \\
\text { Drug load (DL): } 1 \% w / w \\
\end{array}$} & \multirow{2}{*}{$\begin{array}{l}\text { High pressure } \\
\text { homogenization }\end{array}$} & \multirow[t]{2}{*}{$181.2 \pm 0.8$} & \multirow[t]{2}{*}{$-39.2 \pm 1.5$} & \multirow[t]{2}{*}{$0.110 \pm 0.006$} & \multirow[t]{2}{*}{$3.60 \pm 0.23$} & (M) & $\begin{array}{l}\text { Human skin (in vivo } 12 \text { times tape } \\
\text { stripping) }\end{array}$ & \multirow[t]{2}{*}{65} \\
\hline & & & & & & & & (R) & $\begin{array}{l}\text { Amount of drug in SC strips }\left(\mu \mathrm{g} / \mathrm{cm}^{2}\right) \\
\mathrm{L}_{1.5} \mathrm{~S}_{0.5} \mathrm{P}_{2} \mathrm{~A} \\
39.85 \pm 1.29 \\
\text { Control } \mathrm{L}_{2} \mathrm{P}^{2} 0_{2} \mathrm{~A} \\
28.32 \pm 4.39\end{array}$ & \\
\hline \multirow[t]{2}{*}{ Lornoxicam } & \multirow[t]{2}{*}{$\mathrm{L}$} & $\begin{array}{l}\text { Nanoemulsion NE8 } \\
\text { Labrafac }{ }^{\circledR} \\
\text { Tween } 80 \\
\text { Pluronic F-68 }{ }^{\circledR}\end{array}$ & \multirow[t]{2}{*}{$\begin{array}{l}\text { Spontaneous } \\
\text { aqueous phase } \\
\text { titration }\end{array}$} & \multirow[t]{2}{*}{$139 \pm 29$} & & \multirow[t]{2}{*}{0.233} & \multirow[t]{2}{*}{$23.87 \pm 1.86$} & (M) & $\begin{array}{l}\text { Full thickness pig abdominal skin } \\
\text { Receptor: PBS (pH 7.4) }\end{array}$ & \multirow[t]{2}{*}{79} \\
\hline & & $\begin{array}{l}S_{\operatorname{mix}} 3: 1 \\
\text { Oil: } \mathrm{S}_{\operatorname{mix}} 2: 8 \\
\text { Nanoemulsion gel NG8 } \\
\text { NE } 8 \text { gelled with Carbopol } 934^{\circledast} 1 \% \\
\text { Drug load (DL): } 1.5 \%\end{array}$ & & & & & & (R) & $\begin{array}{l}\text { Flux } J\left(\mu g \cdot \mathrm{cm}^{-2} \cdot h^{-1}\right) \text { in } 24 h \\
\text { NE8: } 254.90 \pm 1.25 \\
\text { NG8: } 199.60 \pm 6.93 \\
\text { Control (gel) } \\
43.67 \pm 2.11\end{array}$ & \\
\hline \multirow[t]{2}{*}{ Indomethacin } & \multirow[t]{2}{*}{$\mathrm{L}$} & \multirow[b]{2}{*}{$\begin{array}{l}\text { Nanoemulsion } \mathrm{F} 6(\mathrm{O} / \mathrm{W}) \\
\text { Labrafii }^{\circledR} 5 \% \\
\text { Water } 50 \% \\
\text { Tween } 8033.75 \% \\
\text { Transcutol-HP } \\
\mathrm{S}_{\text {mix }} \text { ratio } 3: 1.25 \% \\
\mathrm{~S}_{\text {mix }} / \text { oil ratio }^{\circ} .00 \\
\text { Nanoemulsion gel NG6 } \\
\text { F6 gelled with Carbopol } 940^{\circledR} 1 \% \\
\text { Triethanolamine } 0.5 \% \\
\text { Drug load (DL): } 0.5 \%\end{array}$} & \multirow{2}{*}{$\begin{array}{l}\text { Spontaneous } \\
\text { aqueous phase } \\
\text { titration }\end{array}$} & \multirow[t]{2}{*}{$\begin{array}{l}\text { F6 } \\
25.53 \pm 2.22\end{array}$} & & \multirow[t]{2}{*}{$\begin{array}{l}\text { F6 } \\
0.087\end{array}$} & $\begin{array}{l}\mathrm{F} 6 \\
14.32 \pm 1.12\end{array}$ & (M) & $\begin{array}{l}\text { Full thickness rat abdominal skin } \\
\text { Receptor: } \\
\text { methanol-PBS (pH 7.4) (1:9) }\end{array}$ & [67] \\
\hline & & & & & & & & (R) & $\begin{array}{l}\text { Flux } J\left(\mu g \cdot \mathrm{cm}^{-2} \cdot \mathrm{h}^{-1}\right) \\
\text { F6: } 73.96 \pm 2.89 \\
\text { NG6: } 61.64 \pm 2.38 \\
\text { Control } \\
\text { Indobene gel }\left(\text { Indo Gel }{ }^{\mathrm{TM}}\right) \\
9.38 \pm 0.41 \\
\text { ER } \\
\text { F6: } 7.88 \\
\text { NG6: } 6.57\end{array}$ & \\
\hline
\end{tabular}


Table 2. Cont

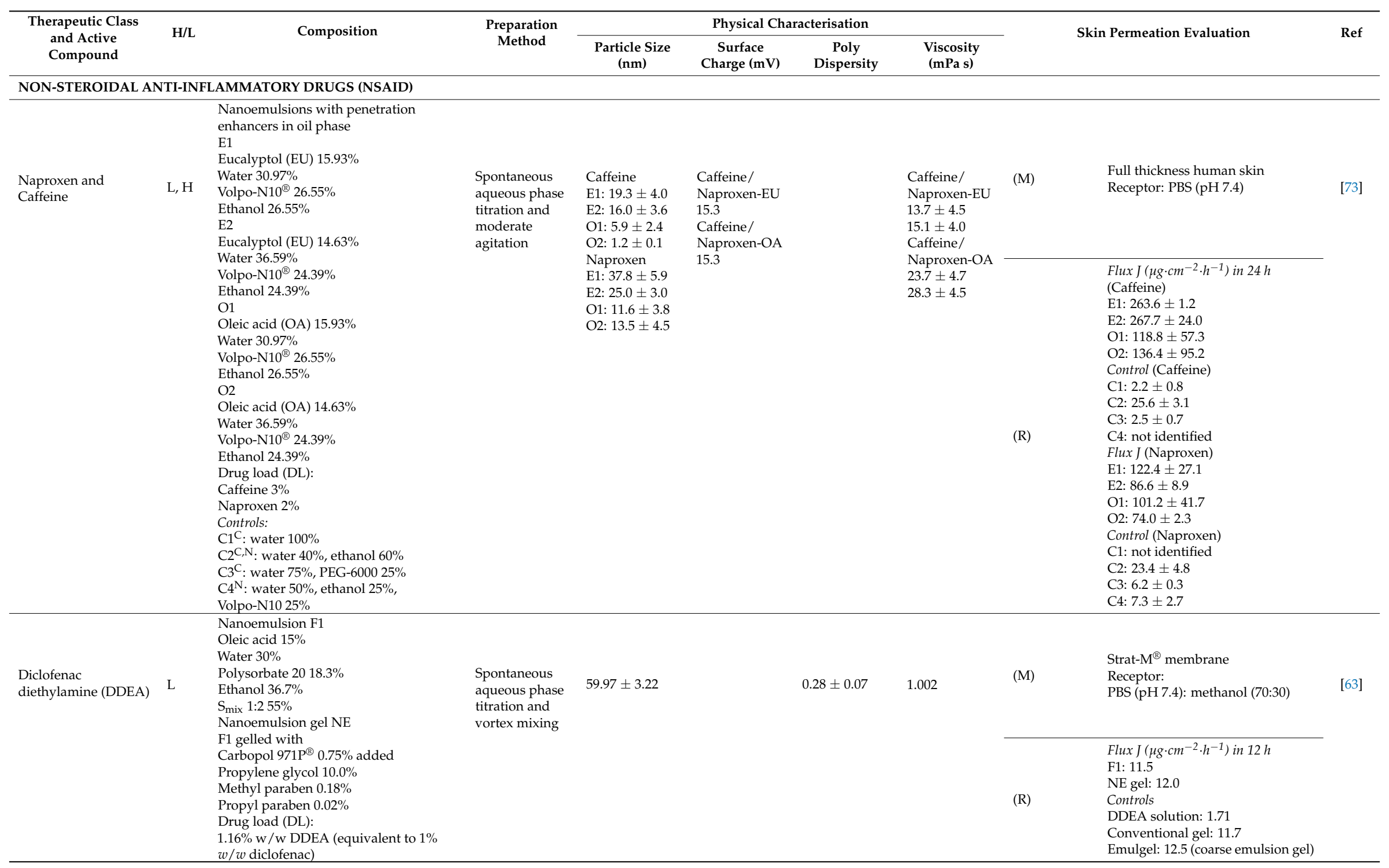


Table 2. Cont.

\begin{tabular}{|c|c|c|c|c|c|c|c|c|c|c|}
\hline \multirow{2}{*}{$\begin{array}{l}\text { Therapeutic Class } \\
\text { and Active } \\
\text { Compound }\end{array}$} & \multirow{2}{*}{$\mathrm{H} / \mathrm{L}$} & \multirow{2}{*}{ Composition } & \multirow{2}{*}{$\begin{array}{l}\text { Preparation } \\
\text { Method }\end{array}$} & \multicolumn{4}{|c|}{ Physical Characterisation } & & \multirow{2}{*}{ Skin Permeation Evaluation } & \multirow{2}{*}{ Ref } \\
\hline & & & & $\begin{array}{c}\text { Particle Size } \\
\text { (nm) }\end{array}$ & $\begin{array}{c}\text { Surface } \\
\text { Charge }(\mathrm{mV}) \\
\end{array}$ & $\begin{array}{c}\text { Poly } \\
\text { Dispersity } \\
\end{array}$ & $\begin{array}{c}\text { Viscosity } \\
\text { (mPa s) }\end{array}$ & & & \\
\hline \multicolumn{11}{|c|}{ NON-STEROIDAL ANTI-INFLAMMATORY DRUGS (NSAID) } \\
\hline \multirow[t]{2}{*}{ Indomethacin } & \multirow[t]{2}{*}{$\mathrm{L}$} & \multirow{2}{*}{$\begin{array}{l}\text { Nanoemulsion } \\
\text { Triacetin }{ }^{\circledR} \\
{\text { Capryol } 90^{\circledR}}^{\circledR} 1: 110 \% \\
\text { Water } 40 \% \\
\text { Tween } 8025 \% \\
\text { Transcutol } 25 \%\end{array}$} & \multirow{2}{*}{$\begin{array}{l}\text { Spontaneous } \\
\text { aqueous phase } \\
\text { titration and } \\
\text { vortex mixing }\end{array}$} & \multirow[t]{2}{*}{101.1} & \multirow[t]{2}{*}{ n.a } & \multirow[t]{2}{*}{ n.a } & \multirow[t]{2}{*}{$60 \pm 2.1$} & $(\mathrm{M})$ & $\begin{array}{l}\text { Full thickness hairless new born } \\
\text { albino rat } \\
\text { Receptor: } \mathrm{PBS}(\mathrm{pH} 7.4)\end{array}$ & \multirow[t]{2}{*}{ [90] } \\
\hline & & & & & & & & (R) & $\begin{array}{l}\text { Flux } J\left(\mu g \cdot \mathrm{cm}^{-2} \cdot h^{-1}\right) \text { in } 6 h \\
55.81 \pm 4.65 \\
\text { No control }\end{array}$ & \\
\hline \multirow[t]{2}{*}{ Meloxicam (MLX) } & \multirow[t]{2}{*}{$\mathrm{L}$} & \multirow{2}{*}{$\begin{array}{l}\text { Drug load (DL): } 1 \% \\
\text { Nanoemulsion gel } \\
\text { Caprylic acid } 0.95 \% \\
\text { Water 70\%Tween } 8020 \% \\
\text { Propylene glycol } 10 \% \\
\text { Carbopol } 940^{\circledR} 0.05 \%\end{array}$} & \multirow{2}{*}{$\begin{array}{l}\text { Spontaneous } \\
\text { aqueous phase } \\
\text { titration }\end{array}$} & \multirow[t]{2}{*}{$125 \pm 1.9$} & \multirow[t]{2}{*}{$-31.85 \pm 0.61$} & \multirow[t]{2}{*}{$0.193 \pm 0.01$} & & (M) & $\begin{array}{l}\text { Abdominal rat skin } \\
\text { Receptor: Acetate buffer } \\
\text { (pH 6.0) }\end{array}$ & \multirow[t]{2}{*}{80} \\
\hline & & & & & & & & (R) & $\begin{array}{l}\text { Flux } J\left(\mu g \cdot \mathrm{cm}^{-2} \cdot h^{-1}\right) \\
6.407 \pm 0.0911 \\
\text { Control (MLX solution): not } \\
\text { identified } \\
\text { Amount in skin layers in } 24 \mathrm{~h} \\
\text { Tape strips: SC level } \\
\text { Control > MLX-NE gel (1.02 folds) } \\
\text { Epidermal level } \\
\text { MLX-NE gel > Control (3.24 folds) } \\
\text { Dermal level } \\
\text { MLX-NE gel > Control (1.42 folds) }\end{array}$ & \\
\hline \multirow[t]{2}{*}{ Flufenamic acid } & \multirow[t]{2}{*}{$\mathrm{L}$} & \multirow{2}{*}{$\begin{array}{l}\text { Nanoemulsion } \\
\text { Potassium sorbate } 0.1 \% \\
\gamma \text {-Cyclodextrin } 1.0 \% \\
\text { Water to } 100 \% \\
\text { PCL-liquid } \\
\text { (cetearyl ethyl hexanoate, isopropyl } \\
\text { myristate) } 20 \% \\
\text { Sucrose stearate S-970 } 2.5 \% \\
\text { Drug load (DL): } 1 \%\end{array}$} & \multirow[t]{2}{*}{$\begin{array}{l}\text { High pressure } \\
\text { homogenization }\end{array}$} & \multirow[t]{2}{*}{-} & \multirow[t]{2}{*}{-} & \multirow[t]{2}{*}{-} & \multirow[t]{2}{*}{-} & (M) & $\begin{array}{l}\text { Dermatomed pig abdominal skin } \\
(1.2 \mathrm{~mm}) \\
\text { Receptor: } \mathrm{PBS}(\mathrm{pH} 7.4)\end{array}$ & \multirow[t]{2}{*}{ [91] } \\
\hline & & & & & & & & (R) & $\begin{array}{l}\text { Flux J }\left(\mu \mathrm{g} \cdot \mathrm{cm}^{-2} \cdot \mathrm{h}^{-1}\right) \\
\gamma-\mathrm{SN} \text { Fluf } \\
1.83 \pm 0.87 \\
\text { No control }\end{array}$ & \\
\hline
\end{tabular}


Table 2. Cont.

\begin{tabular}{|c|c|c|c|c|c|c|c|c|c|c|}
\hline \multirow{2}{*}{$\begin{array}{l}\text { Therapeutic Class } \\
\text { and Active } \\
\text { Compound }\end{array}$} & \multirow{2}{*}{$H / L$} & \multirow{2}{*}{ Composition } & \multirow{2}{*}{$\begin{array}{l}\text { Preparation } \\
\text { Method }\end{array}$} & \multicolumn{4}{|c|}{ Physical Characterisation } & \multirow{2}{*}{\multicolumn{2}{|c|}{ Skin Permeation Evaluation }} & \multirow{2}{*}{ Ref } \\
\hline & & & & $\begin{array}{l}\text { Particle Size } \\
(\mathrm{nm})\end{array}$ & $\begin{array}{c}\text { Surface } \\
\text { Charge (mV) }\end{array}$ & $\begin{array}{c}\text { Poly } \\
\text { Dispersity }\end{array}$ & $\begin{array}{l}\text { Viscosity } \\
\text { (mPa s) }\end{array}$ & & & \\
\hline \multicolumn{11}{|c|}{ ANTIFUNGAL AGENTS } \\
\hline \multirow{2}{*}{$\begin{array}{l}\text { Terbinafine (TER) } \\
\text { Citral (CIT) }\end{array}$} & \multirow[t]{2}{*}{$\begin{array}{l}\mathrm{L} \\
\mathrm{L}\end{array}$} & \multirow[b]{2}{*}{$\begin{array}{l}\text { Nanoemulsion (NE) } \\
\text { CIT 4\% } \\
\text { Water 71\% } \\
\text { Cremophor EL-40 } 40^{\circledR} 18 \% \\
\text { 1,2-propylene glycol } 6 \% \\
\text { Smix 3:1 } \\
\text { NG1 } \\
\text { NE gelled with Carbopol } 934^{\circledR} \\
1 \% 1: 1 \\
\text { (NG2 and NG3 contain } 2 \% \text { and } 3 \% \\
\text { Carbopol } 934^{\circledR}, \text { respectively, at the same } \\
\text { ratio with NE) } \\
\text { Drug load (DL) in NE } \\
\text { TER 1\% and CIT } 4 \% \text { (oil phase) } \\
\text { Controls: TER-CIT in Conventional gels } \\
\left(1.5 \% \text { Carbopol } 934^{\circledR} \text { ) }\right.\end{array}$} & \multirow{2}{*}{$\begin{array}{l}\text { Spontaneous } \\
\text { aqueous phase } \\
\text { titration }\end{array}$} & \multirow{2}{*}{$\begin{array}{l}\mathrm{NE} \\
15.53 \pm 3.32 \\
\mathrm{NG} 1 \\
14.88 \pm 3.11\end{array}$} & \multirow{2}{*}{$\begin{array}{l}\mathrm{NE} \\
-7.4 \pm 1.8 \\
\mathrm{NG} 1 \\
-6.5 \pm 2.3\end{array}$} & \multirow{2}{*}{$\begin{array}{l}\mathrm{NE} \\
0.074 \pm 0.009 \\
\mathrm{NG} 1 \\
0.084 \pm 0.025\end{array}$} & & (M) & $\begin{array}{l}\text { Guinea pig abdominal skin } \\
\text { Receptor: PBS (pH 7.4) }\end{array}$ & [93] \\
\hline & & & & & & & & (R) & 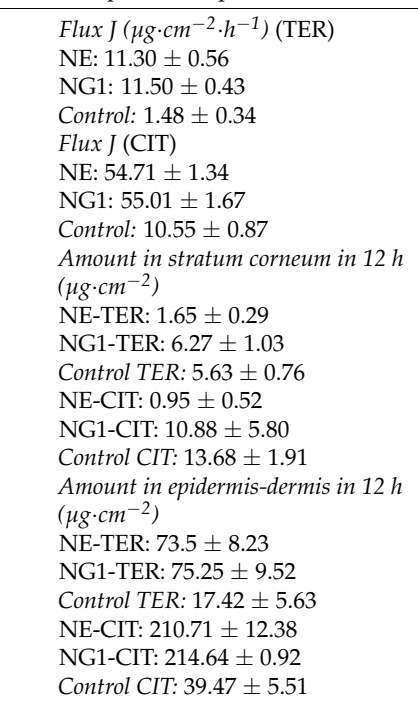 & \\
\hline \multirow[t]{2}{*}{ Fluconazole } & \multirow[t]{2}{*}{$\mathrm{H}$} & \multirow{2}{*}{$\begin{array}{l}\text { Lecithin based NE } \\
\text { PCL-liquid (cetearyl ethyl hexanoate, } \\
\text { isopropyl myristate) } 20 \% \\
\text { Potassium sorbate } 0.1 \% \\
\gamma \text {-Cyclodextrin } 1.0 \% \\
\text { Water to } 100 \% \\
\text { Lipoid E- } 800^{\circledR} 2.5 \% \\
\text { Drug load (DL): } 1 \% \\
\end{array}$} & \multirow[t]{2}{*}{$\begin{array}{l}\text { High pressure } \\
\text { homogenization }\end{array}$} & \multirow{2}{*}{$\begin{array}{l}\text { LN Fluc } \\
156.87 \pm 09.73 \\
\gamma \text {-LN Fluc } \\
155.60 \pm 07.96\end{array}$} & \multirow{2}{*}{$\begin{array}{l}\text { LN Fluc } \\
-24.70 \pm 3.41 \\
\gamma \text {-LN Fluc } \\
-22.50 \pm 2.20\end{array}$} & \multirow{2}{*}{$\begin{array}{l}\text { LN Fluc } \\
0.05 \pm 0.01 \\
\gamma \text {-LN Fluc } \\
0.07 \pm 0.02\end{array}$} & & (M) & $\begin{array}{l}\text { Dermatomed pig abdominal skin } \\
(1.2 \mathrm{~mm}) \\
\text { Receptor: PBS (pH 7.4) }\end{array}$ & \multirow[t]{2}{*}{ [91] } \\
\hline & & & & & & & & (R) & $\begin{array}{l}\text { Flux } J\left(\mu g \cdot \mathrm{cm}^{-2} \cdot h^{-1}\right) \\
\text { LN Fluc: } 109.55 \pm 11.30 \\
\gamma \text {-LN Fluc: } 93.63 \pm 3.80 \\
\text { No control }\end{array}$ & \\
\hline
\end{tabular}


Table 2. Cont

\begin{tabular}{|c|c|c|c|c|c|c|c|c|c|c|}
\hline \multirow{2}{*}{$\begin{array}{l}\text { Therapeutic Class } \\
\text { and Active } \\
\text { Compound }\end{array}$} & \multirow{2}{*}{$\mathrm{H} / \mathrm{L}$} & \multirow{2}{*}{ Composition } & \multirow{2}{*}{$\begin{array}{l}\text { Preparation } \\
\text { Method }\end{array}$} & \multicolumn{4}{|c|}{ Physical Characterisation } & & \multirow{2}{*}{ Skin Permeation Evaluation } & \multirow{2}{*}{ Ref } \\
\hline & & & & $\begin{array}{c}\text { Particle Size } \\
(\mathrm{nm})\end{array}$ & $\begin{array}{c}\text { Surface } \\
\text { Charge (mV) }\end{array}$ & $\begin{array}{c}\text { Poly } \\
\text { Dispersity }\end{array}$ & $\begin{array}{l}\text { Viscosity } \\
\text { (mPa s) }\end{array}$ & & & \\
\hline \multicolumn{11}{|l|}{ CORTICOSTEROIDS } \\
\hline \multirow[t]{2}{*}{$\begin{array}{l}\text { Fludrocortisone } \\
\text { acetate }\end{array}$} & \multirow[t]{2}{*}{$\mathrm{L}$} & \multirow{2}{*}{$\begin{array}{l}\text { Lecithin based NE } \\
\text { PCL-liquid (cetearyl ethyl hexanoate, } \\
\text { isopropyl myristate) } \\
20 \% \\
\text { Potassium sorbate } 0.1 \% \\
\gamma \text {-Cyclodextrin } 0.5 \% \text { or } 1.0 \% \\
\text { Water to } 100 \% \\
\text { Lecithin } E-80^{\circledR} 2.5 \% \\
\text { Drug load (DL): } 1 \%\end{array}$} & \multirow[t]{2}{*}{$\begin{array}{l}\text { High pressure } \\
\text { homogenization }\end{array}$} & \multirow{2}{*}{$\begin{array}{l}\gamma-0.5 \% \mathrm{NE} \\
171.03 \pm 0.32 \\
\gamma-1 \% \mathrm{NE} \\
169.73 \pm 2.35\end{array}$} & \multirow{2}{*}{$\begin{array}{l}\gamma-0.5 \% \mathrm{NE} \\
-33.17 \pm 0.75 \\
\gamma-1 \% \mathrm{NE} \\
-31.73 \pm 1.52\end{array}$} & \multirow{2}{*}{$\begin{array}{l}\gamma-0.5 \% \mathrm{NE} \\
0.098 \pm 0.042 \\
\gamma-1 \% \mathrm{NE} \\
0.033 \pm 0.049\end{array}$} & & (M) & $\begin{array}{l}\text { Dermatomed pig abdominal skin } \\
(1.2 \mathrm{~mm}) \\
\text { Receptor: PBS (pH 7.4) }\end{array}$ & \multirow[t]{2}{*}{ [94] } \\
\hline & & & & & & & & (R) & $\begin{array}{l}\text { Flux J }\left(\mu g \cdot \mathrm{cm}^{-2} \cdot h^{-1}\right) \text { in } 24 h \\
\text { Finite dose } \\
\gamma-1 \% \mathrm{NE} \\
0.067 \pm 0.047 \\
\mathrm{NE} \text { Control: } \\
0.008 \pm 0.007 \\
\text { Infinite dose } \\
\gamma-1 \% \mathrm{NE} \\
2.48 \pm 0.68 \\
\mathrm{NE} \text { Control: } \\
0.09 \pm 0.07 \\
E R \text { of } \gamma-1 \% \mathrm{NE}: \text { finite dose } 8.38 \\
\text { infinite dose } 27.55 \\
\text { Control: } \mathrm{NE} \text { without cyclodextrin } \\
\text { Applied as finite }\left(5 \mathrm{mg} / \mathrm{cm}^{2}\right) \text { and } \\
\text { infinite doses }\left(500 \mathrm{mg} / \mathrm{cm}^{2}\right) \\
\text { No significant different in drug } \\
\text { flux between } \gamma-1 \% \mathrm{NE} \text { and } \gamma-0.5 \% \\
\mathrm{NE}\end{array}$ & \\
\hline \multirow{2}{*}{$\begin{array}{l}\text { Fludrocortisone } \\
\text { acetate (FA) } \\
\text { Flumethasone } \\
\text { pivalate (FP) }\end{array}$} & \multirow[t]{2}{*}{$\mathrm{L}$} & \multirow[b]{2}{*}{$\begin{array}{l}\text { Nanoemulsion } \\
\text { (positive charge) } \\
\text { PCL-liquid (cetearyl ethyl hexanoate, } \\
\text { isopropyl myristate) } 20 \% \\
\text { Lipoid S-75 } 4 \% \\
\alpha \text { tocopherol } 1 \% \\
\text { Phytosphingosine (PS) } 0.4 \% \text { or } 0.6 \% \\
\text { Water to } 100 \% \\
\text { Sucrose laurate L-1695 1\% } \\
\text { or } \\
\text { Tween } 801 \% \\
\text { Drug load (DL): } 1 \% \\
\text { FA NL: FA NE with sucrose laurate } \\
\text { L-1695 } \\
\text { FA NT: FA NE with tween } 80 \text { FP NL: FP } \\
\text { NE with sucrose laurate L-1695 } \\
\text { FP NT: FP NE with tween } 80\end{array}$} & \multirow[t]{2}{*}{$\begin{array}{l}\text { High pressure } \\
\text { homogenization }\end{array}$} & \multirow[b]{2}{*}{$\begin{array}{l}\text { FA NL } \\
161 \pm 0.7 \\
\text { FA NL-0.4PS } \\
215 \pm 2.8 \\
\text { FA NL-0.6PS } \\
254 \pm 2.2 \\
\text { FA NT } \\
170 \pm 3.8 \\
\text { FA NT- } 0.4 \text { PS } \\
216 \pm 26.6 \\
\text { FA NT-0.6PS } \\
170 \pm 2.1\end{array}$} & \multirow[b]{2}{*}{$\begin{array}{l}\text { FA NL } \\
-6.2 \pm 0.4 \\
\text { FA NL- } 0.4 \text { PS } \\
+46 \pm 0.4 \\
\text { FA NL-0.6PS } \\
+48 \pm 0.7 \\
\text { FA NT } \\
-55 \pm 0.7 \\
\text { FA NT-0.4PS } \\
+45 \pm 0.7 \\
\text { FA NT- } 0.6 \text { PS } \\
+48 \pm 1.1\end{array}$} & \multirow[b]{2}{*}{$\begin{array}{l}\text { FA NL } \\
0.12-0.22 \\
\text { FA N--0.4PS } \\
0.22-0.25 \\
\text { FA NL-0.6 PS } \\
0.06-0.1 \\
\text { FA NT } \\
0.15-0.18 \\
\text { FA NT-0.4PS } \\
0.13-0.18 \\
\text { FA NT-0.6 PS } \\
0.10-0.14\end{array}$} & & (M) & $\begin{array}{l}\text { Dermatomed pig abdominal skin } \\
(1 \mathrm{~mm}) \\
\text { Receptor: PBS (pH 7.4) }\end{array}$ & \multirow[t]{2}{*}{ [95] } \\
\hline & & & & & & & & (R) & $\begin{array}{l}\text { Flux } J\left(\mu g \cdot \mathrm{cm}^{-2} \cdot h^{-1}\right) \text { in } 48 h \\
\text { FA NL } \\
0.126 \pm 0.027 \\
\text { FA NL-0.4PS } \\
0.150 \pm 0.010 \\
\text { FA NL-0.6 PS } \\
0.189 \pm 0.012 \\
\text { FA NT } \\
0.263 \pm 0.043 \\
\text { FA NT-0.4PS } \\
0.353 \pm 0.018 \\
\text { FA NT-0.6 PS } \\
0.377 \pm 0.038 \\
\text { FP NT } \\
2.290 \pm 0.313 \\
\text { FP NT-0.4PS } \\
2.698 \pm 0.117 \\
\text { FP NT-0.6 PS } \\
3.073 \pm 0.104 \\
\text { No control } \\
\text { Flux increased with PS } \\
\text { concentration; Tween } 80>\text { sucrose } \\
\text { laurate }\end{array}$ & \\
\hline
\end{tabular}


Table 2. Cont.

\begin{tabular}{|c|c|c|c|c|c|c|c|c|c|c|}
\hline \multirow{2}{*}{$\begin{array}{l}\text { Therapeutic Class } \\
\text { and Active } \\
\text { Compound }\end{array}$} & \multirow{2}{*}{$H / L$} & \multirow{2}{*}{ Composition } & \multirow{2}{*}{$\begin{array}{l}\text { Preparation } \\
\text { Method }\end{array}$} & \multicolumn{4}{|c|}{ Physical Characterisation } & \multirow{2}{*}{\multicolumn{2}{|c|}{ Skin Permeation Evaluation }} & \multirow{2}{*}{ Ref } \\
\hline & & & & $\begin{array}{c}\text { Particle Size } \\
(\mathrm{nm})\end{array}$ & $\begin{array}{c}\text { Surface } \\
\text { Charge }(\mathrm{mV})\end{array}$ & $\begin{array}{c}\text { Poly } \\
\text { Dispersity }\end{array}$ & $\begin{array}{l}\text { Viscosity } \\
\text { (mPa s) }\end{array}$ & & & \\
\hline \multicolumn{11}{|l|}{ CORTICOSTEROIDS } \\
\hline \multirow[t]{2}{*}{ Prednicarbate (PC) } & \multirow[t]{2}{*}{$\mathrm{L}$} & \multirow{2}{*}{$\begin{array}{l}\text { Positively charged NE (PCNE) } \\
\text { Phytosphingosine (PS) } 0.6 \% \\
\text { Lecithin E- } 80^{\circledR}, \text { Tween } 802 \% \\
\text { Ethanol } 20 \% \\
\alpha \text { tocopherol } 0.03 \% \\
\text { Potassium sorbate } 0.1 \% \\
\text { Negatively charged NE (NCNE) } \\
\text { Myristic acid } 1 \% \text { was used to replace PS } \\
\text { Drug load (DL): } 0.25 \%\end{array}$} & \multirow[t]{2}{*}{$\begin{array}{l}\text { High pressure } \\
\text { homogenization }\end{array}$} & \multirow[t]{2}{*}{$\begin{array}{l}\text { PCNE: } 157 \\
\text { NCNE: } 136\end{array}$} & \multirow{2}{*}{$\begin{array}{l}\text { PCNE: } 50-60 \\
\text { NCNE: } \\
-(40-50)\end{array}$} & \multirow[t]{2}{*}{$0.05-0.1$} & & (M) & $\begin{array}{l}\text { Full thickness human skin } \\
\text { Receptor: Ethanol-PBS (1:1) } \\
\text { No PC detected in receptor in } 24 \mathrm{~h}\end{array}$ & \multirow[t]{2}{*}{$\begin{array}{l}{[53,} \\
54]\end{array}$} \\
\hline & & & & & & & & (R) & $\begin{array}{l}\text { Amount PC in skin in } 24 \mathrm{~h} \\
\text { PCNE: } 18.4 \pm 3.4 \mu \mathrm{g} / \mathrm{mL} \\
\text { NCNE }: 11.7 \pm 2.5 \mu \mathrm{g} / \mathrm{mL} \\
\text { No control } \\
\text { Positive }>\text { negative charged NE }\end{array}$ & \\
\hline \multirow[t]{2}{*}{$\begin{array}{l}\text { Fludrocortisone } \\
\text { acetate (FA) }\end{array}$} & \multirow[t]{2}{*}{$\mathrm{L}$} & $\begin{array}{l}\text { Lecithin based NE } \\
\text { PCL-liquid (cetearyl ethyl hexanoate, } \\
\text { isopropyl myristate) } 20 \% \\
\text { Lecithin E-80 } 20^{\circledR} .5 \%\end{array}$ & \multirow[t]{2}{*}{$\begin{array}{l}\text { High pressure } \\
\text { homogenization }\end{array}$} & \multirow[t]{2}{*}{$\begin{array}{l}\gamma \text {-LN Flud } \\
175.82 \pm 00.47\end{array}$} & \multirow[t]{2}{*}{$\begin{array}{l}\gamma \text {-LN Flud } \\
-30.19 \pm 4.12\end{array}$} & \multirow[t]{2}{*}{$\begin{array}{l}\gamma \text {-LN Flud } \\
0.09 \pm 0.04\end{array}$} & & (M) & $\begin{array}{l}\text { Dermatomed pig abdominal skin } \\
\text { (1.2mm thick) } \\
\text { Receptor: PBS (pH 7.4) }\end{array}$ & \multirow[t]{2}{*}{ [91] } \\
\hline & & $\begin{array}{l}\gamma \text {-Cyclodextrin } 1.0 \% \\
\text { Water to } 100 \% \\
\text { Drug load (DL): } 1 \%\end{array}$ & & & & & & (R) & $\begin{array}{l}\text { Flux } J\left(\mu g \cdot \mathrm{cm}^{-2} \cdot h^{-1}\right)(\mathrm{FA}) \\
\gamma \text {-LN Flud: } 4.53 \pm 0.99 \\
\text { No control }\end{array}$ & \\
\hline \multicolumn{11}{|l|}{ VITAMINS } \\
\hline \multirow[t]{2}{*}{$\begin{array}{l}\alpha \text { tocopherol } \\
\text { (vitamin E) }\end{array}$} & \multirow[t]{2}{*}{$\mathrm{L}$} & $\begin{array}{l}\text { Hyaluronic acid-based NE (L6) } \\
\text { Methylene oxide (O) } \\
\text { Tween 80-Span 20 (S) } \\
\text { HA-GMS solution (A) } \\
\text { Mass ratio O:S:A 2:3:95 }\end{array}$ & \multirow{2}{*}{$\begin{array}{l}\text { Oil/water/surfact } \\
\text { emulsifying } \\
\text { system and } \\
\text { solvent } \\
\text { evaporation }\end{array}$} & \multirow[t]{2}{*}{$57.3 \pm 0.2$} & & \multirow[t]{2}{*}{0.260} & & (M) & $\begin{array}{l}\text { Full thickness Wistar rat dorsal } \\
\text { skin } \\
\text { Receptor: PBS (pH 7.4) }\end{array}$ & \multirow[t]{2}{*}{ [96] } \\
\hline & & $\begin{array}{l}\text { Drug load (DL): } 0.1 \% \\
\text { HA-GMS is water soluble amphiphile } \\
\text { from crosslinking esterification of } \\
\text { hyaluronic acid and glycerol } \alpha \text {-mono } \\
\text { stearate (stearin) }\end{array}$ & & & & & & (R) & $\begin{array}{l}\text { Flux } J\left(\mu g \cdot \mathrm{cm}^{-2} \cdot \mathrm{h}^{-1}\right) \text { in } 24 \mathrm{~h} \\
\text { L6: } 14.68 \pm 4.13 \\
\text { Control: not detected } \\
\text { Control: } 0.1 \% \text { vitamin E in ethanol } \\
\text { solution }\end{array}$ & \\
\hline \multirow{2}{*}{$\begin{array}{l}\alpha \text { tocopherol (vitamin } \\
\text { E) and Vitamin K1 } \\
\text { (VK1) }\end{array}$} & \multirow[t]{2}{*}{$\mathrm{L}$} & \multirow{2}{*}{$\begin{array}{l}\text { Nanoemulsions } \\
\alpha \text {-tocopherol }(\alpha \text {-TOC), VK1 } \\
10 \% \\
\text { Water } 64 \% \\
\text { Tween } 8010 \% \\
\text { Ethanol 16\% } \\
\text { Drug load (DL): } 3 \% \text { or } 5 \%\end{array}$} & \multirow{2}{*}{$\begin{array}{l}\text { Spontaneous } \\
\text { aqueous phase } \\
\text { titration and } \\
\text { Ultrasonic } \\
\text { nebulization } \\
\text { NE-neb-VK1 }= \\
\text { ultrasonic } \\
\text { nebulizer }\end{array}$} & \multirow{2}{*}{$\begin{array}{l}\text { NE-VK1 } 3 \% \\
254.8 \pm 10.7 \\
\text { NE-neb-VK1 } \\
3 \% \\
259.4 \pm 4.1 \\
\text { NE-VK1 } 5 \% \\
215.7 \pm 2.3 \\
\text { NE-neb-VK1 } \\
5 \% \\
233.2 \pm 0.2\end{array}$} & \multirow{2}{*}{$\begin{array}{l}\text { NE-VK1 } 3 \% \\
-14.89 \pm 2.68 \\
\text { NEs-neb-VK1 } \\
3 \% \\
-16.60 \pm 1.01 \\
\text { NE-VK1 } 5 \% \\
-14.14 \pm 0.29 \\
\text { NE-neb-VK1 } \\
5 \% \\
-15.4 \pm 0.1\end{array}$} & \multirow{2}{*}{$\begin{array}{l}\text { NE-VK1 } 3 \% \\
0.22 \pm 0.05 \\
\text { NEs-neb-VK1 } \\
3 \% \\
0.19 \pm 0.14 \\
\text { NE-VK1 } \% \\
0.23 \pm 0.02 \\
\text { NE-neb-VK1 } \\
5 \% \\
0.26 \pm 0.02\end{array}$} & & (M) & $\begin{array}{l}\text { Pig ear skin (thickness } 1.7-2.3 \mathrm{~mm}) \\
\text { Receptor: PBS : Ethanol } \\
(7: 3 \mathrm{v} / \mathrm{v})\end{array}$ & [56] \\
\hline & & & & & & & & (R) & $\begin{array}{l}\text { Amount in epidermis in } 24 \mathrm{~h}(\mathrm{ng} / \mathrm{mg}) \\
\text { NEs-VK1 3\%: } 46.7 \\
\text { NEs-neb-VK1 3\%: } 72.8 \\
\text { NEs-VK1 5\%: 55.6 } \\
\text { NEs-neb-VK1 5\%: } 51.4 \\
\text { Amount in dermis in } 24 \text { h (ng/mg) } \\
\text { NEs-neb-VK1 3\%: } 27.9 \\
\text { NEs-neb-VK1 5\%: } 24.8 \\
\text { No control }\end{array}$ & \\
\hline
\end{tabular}


Table 2. Cont

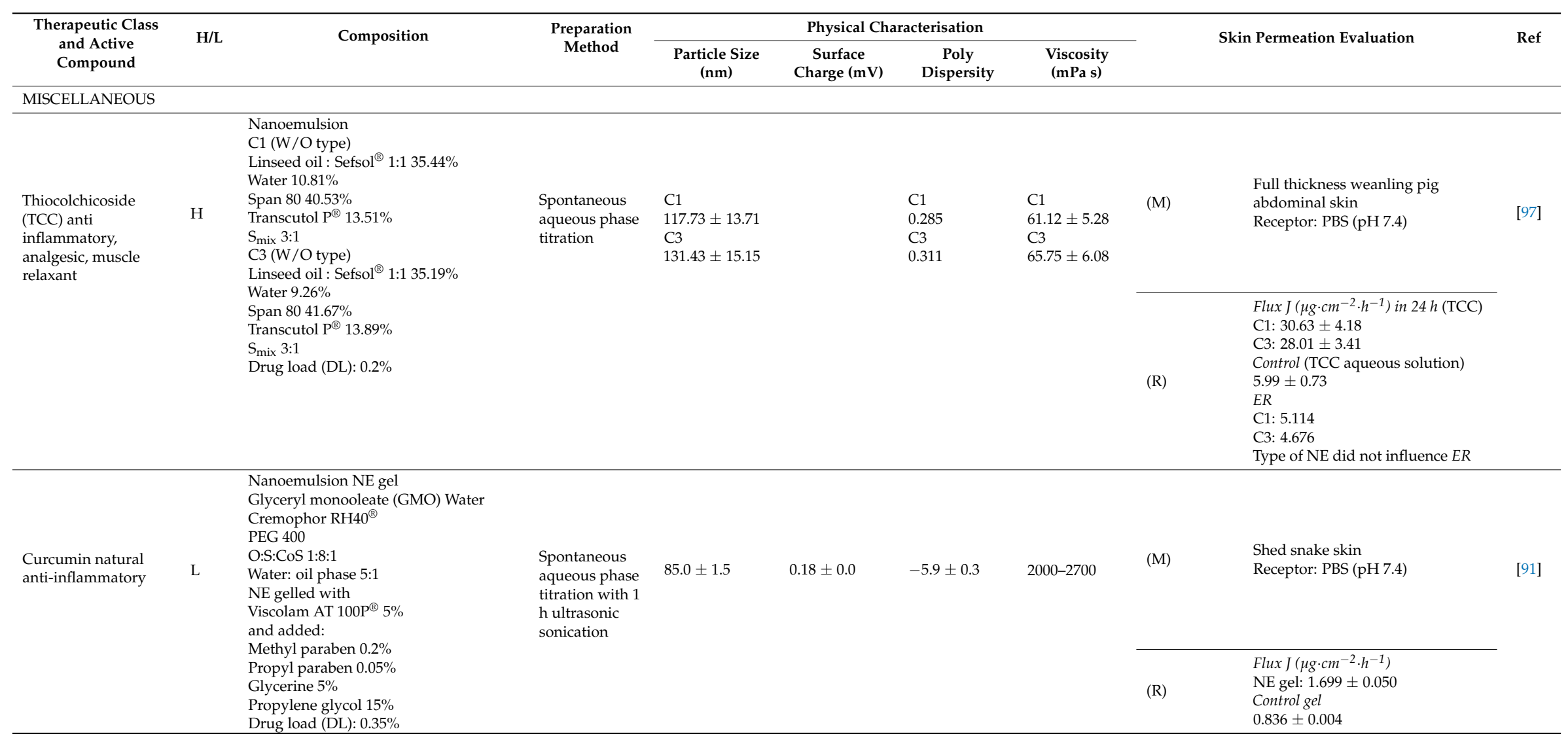


Table 2. Cont

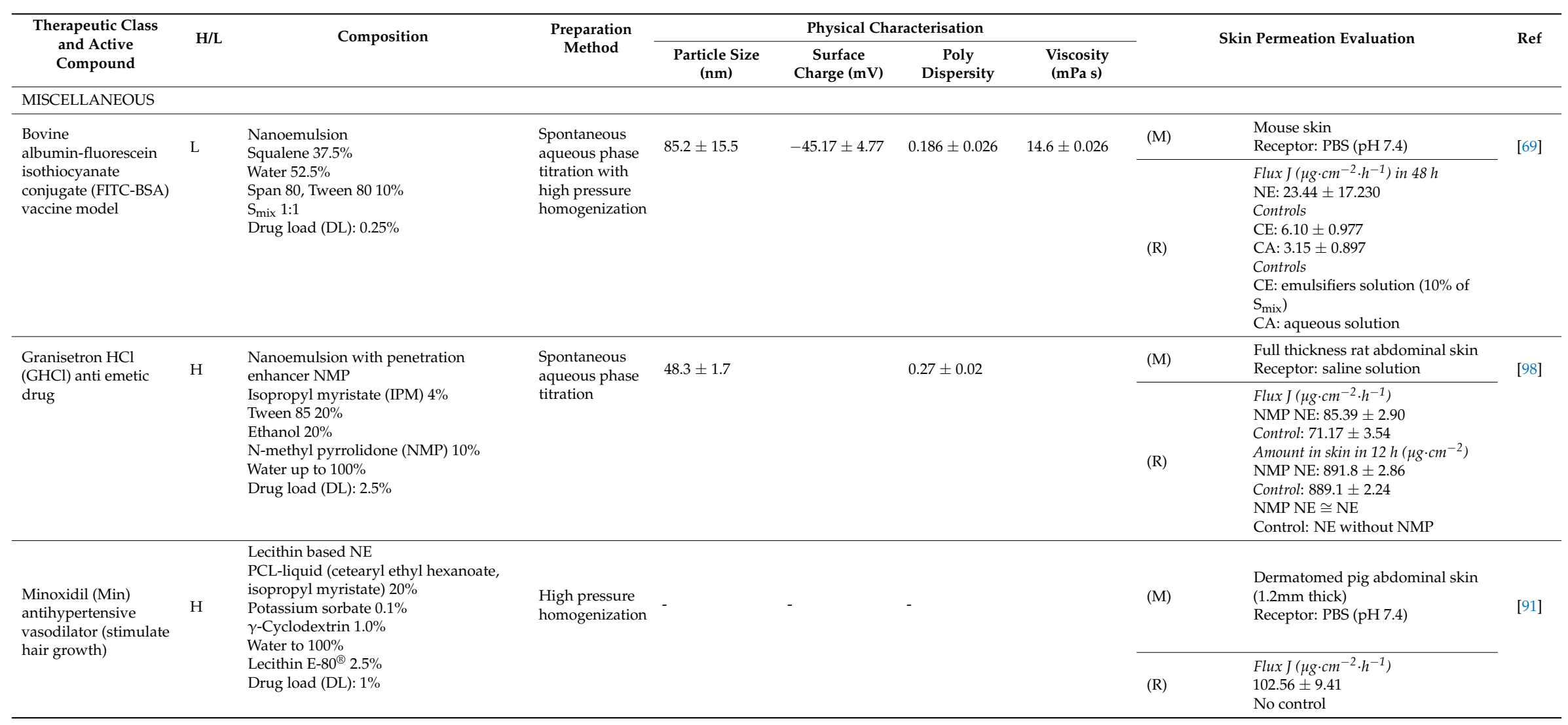


Ensuring that any novel formulation maintains the stability and therapeutic activity of the drug is essential. The anti-inflammatory activity of NSAIDs applied in ME formulations has been demonstrated in a number of studies. For example, ME [o/w: composed of isopropyl myristate, water, Capmul $\mathrm{MCM}^{\circledR}$ (mixture of medium chain glycerides), Tween 80], gel (added Carbopol ${ }^{\circledR}$ 934), and cream (anionic emulsifying ointment and water) formulations containing celecoxib were compared for permeation across excised full-thickness rat skin [70]. Selected formulations were evaluated using the arachidonic acid induced ear edema model in Swiss albino mice. The skin permeation of celecoxib from the ME formulations was 3 to 5-fold greater than ME gels, and 7 to 11-fold greater than the cream. Increasing the concentration of Capmul $\mathrm{MCM}^{\circledR}$ in the $\mathrm{ME}$ resulted in an increase of droplet size and viscosity and decrease in celecoxib diffusion coefficient. Administration of selected ME formulations reduced ear edema by up to $55 \%$ demonstrating that the celecoxib ME was an effective anti-inflammatory formulation.

\section{Conclusions and Future Directions}

$\mathrm{ME}$ and NE have a clear place in the delivery of active compounds to and through the skin for a range of therapeutic purposes. They are elegant, relatively simple and inexpensive to manufacture and offer significant delivery advantages over coarse emulsions. Over the past few decades, there has been extensive research demonstrating the effectiveness of these delivery technologies. In addition, the development of new excipients with potential utility in NE and ME formulations continues to offer new opportunities for formulations with high delivery capacity coupled with low irritancy and toxicity. Although it has been explored, the precise mechanism of delivery of these formulations remains controversial, but it is likely to be a combination of the effect of the formulation components on stratum corneum diffusivity of the active compounds. The increase in transfollicular penetration from NE and ME is well established and is again likely due to both the formulation components facilitating penetration through the sebum and within the follicle. Given the advantages of these systems and the continued development of low toxicity excipients, it is likely that we will continue to see new NE and ME products for topical and transdermal delivery into the future.

Acknowledgments: Michael Roberts acknowledges the support of grants from the National Health and Medical Research Council of Australia (APP1049906; 1002611) and the US FDA (U01FD005226; U01FD005232). Christofori Nastiti acknowledges the Australia Awards Scholarship from the Department of Foreign Affairs and Trade, Australia.

Author Contributions: All authors contributed to the literature review and critical analysis, drafting and editing of this manuscript.

Conflicts of Interest: The authors declare no conflicts of interest.

\section{References}

1. Scheuplein, R.J. Analysis of permeability data for the case of parallel diffusion pathways. Biophys. J. 1966, 6, 1-17. [CrossRef]

2. Scheuplein, R.J.; Blank, I.H. Permeability of the skin. Physiol. Rev. 1971, 51, 702-747. [PubMed]

3. Kasting, G.B.; Barai, N.D.; Wang, T.F.; Nitsche, J.M. Mobility of water in human stratum corneum. J. Pharm. Sci. 2003, 92, 2326-2340. [CrossRef] [PubMed]

4. Illel, B.; Schaefer, H.; Wepierre, J.; Doucet, O. Follicles play an important role in percutaneous absorption. J. Pharm. Sci. 1991, 80, 424-427. [CrossRef] [PubMed]

5. Roberts, M.S.; Mohammed, Y.; Pastore, M.N.; Namjoshi, S.; Yousef, S.; Alinaghi, A.; Haridass, I.N.; Abd, E.; Leite-Silva, V.R.; Benson, H.; et al. Topical and cutaneous delivery using nanosystems. J. Control. Release 2017, 247, 86-105. [CrossRef] [PubMed]

6. Leite-Silva, V.R.; Liu, D.C.; Sanchez, W.Y.; Studier, H.; Mohammed, Y.H.; Holmes, A.; Becker, W.; Grice, J.E.; Benson, H.A.; Roberts, M.S. Effect of flexing and massage on in vivo human skin penetration and toxicity of zinc oxide nanoparticles. Nanomedicine (Lond.) 2016, 11, 1193-1205. [CrossRef] [PubMed] 
7. Leite-Silva, V.R.; Sanchez, W.Y.; Studier, H.; Liu, D.C.; Mohammed, Y.H.; Holmes, A.M.; Ryan, E.M.; Haridass, I.N.; Chandrasekaran, N.C.; Becker, W.; et al. Human skin penetration and local effects of topical nano zinc oxide after occlusion and barrier impairment. Eur. J. Pharm. Biopharm. 2016, 104, 140-147. [CrossRef] [PubMed]

8. Danielsson, I.; Lindman, B. The definition of microemulsion. Colloid Surf. 1981, 3, 391-392. [CrossRef]

9. Muller, R.H.; Radtke, M.; Wissing, S.A. Solid lipid nanoparticles (SLN) and nanostructured lipid carriers (NLC) in cosmetic and dermatological preparations. Adv. Drug Deliv. Rev. 2002, 54 (Suppl. 1), S131-S155. [CrossRef]

10. Jores, K.; Haberland, A.; Wartewig, S.; Mader, K.; Mehnert, W. Solid lipid nanoparticles (SLN) and oil-loaded SLN studied by spectrofluorometry and Raman spectroscopy. Pharm. Res. 2005, 22, 1887-1897. [CrossRef] [PubMed]

11. Touitou, E.; Dayan, N.; Bergelson, L.; Godin, B.; Eliaz, M. Ethosomes-Novel vesicular carriers for enhanced delivery: Characterization and skin penetration properties. J. Control. Release 2000, 65, 403-418. [CrossRef]

12. Uchegbu, I.F.; Vyas, S.P. Non-ionic surfactant based vesicles (niosomes) in drug delivery. Int. J. Pharm. 1997, 172, 33-70. [CrossRef]

13. Dragicevic-Curic, N.; Scheglmann, D.; Albrecht, V.; Fahr, A. Temoporfin-loaded invasomes: Development, characterization and in vitro skin penetration studies. J. Control. Release 2008, 127, 59-69. [CrossRef] [PubMed]

14. Geusens, B.; van Gele, M.; Braat, S.; de Smedt, S.C.; Stuart, M.C.; Prow, T.W.; Sanchez, W.; Roberts, M.S.; Sanders, N.; Lambert, J. Flexible Nanosomes (SECosomes) Enable Efficient siRNA Delivery in Cultured Primary Skin Cells and in the Viable Epidermis of Ex Vivo Human Skin. Adv. Funct. Mater. 2010, 20, 4077-4090. [CrossRef]

15. Mura, S.; Manconi, M.; Fadda, A.M.; Sala, M.C.; Perricci, J.; Pini, E.; Sinico, C. Penetration enhancercontaining vesicles (PEVs) as carriers for cutaneous delivery of minoxidil: In vitro evaluation of drug permeation by infrared spectroscopy. Pharm. Dev. Technol. 2013, 18, 1339-1345. [CrossRef] [PubMed]

16. Manconi, M.; Caddeo, C.; Sinico, C.; Valenti, D.; Mostallino, M.C.; Biggio, G.; Fadda, A.M. Ex vivo skin delivery of diclofenac by transcutol containing liposomes and suggested mechanism of vesicle-skin interaction. Eur. J. Pharm. Biopharm. 2011, 78, 27-35. [CrossRef] [PubMed]

17. Williams, A.C.; Barry, B.W. Penetration enhancers. Adv. Drug Deliv. Rev. 2004, 56, 603-618. [CrossRef] [PubMed]

18. Cevc, G.; Blume, G. Lipid vesicles penetrate into intact skin owing to the transdermal osmotic gradients and hydration force. Biochim. Biophys. Acta 1992, 1104, 226-232. [CrossRef]

19. Kim, S.; Shi, Y.; Kim, J.Y.; Park, K.; Cheng, J.X. Overcoming the barriers in micellar drug delivery: Loading efficiency, in vivo stability, and micelle-cell interaction. Exp. Opin. Drug Deliv. 2010, 7, 49-62. [CrossRef] [PubMed]

20. Borowska, K.; Wolowiec, S.; Glowniak, K.; Sieniawska, E.; Radej, S. Transdermal delivery of 8-methoxypsoralene mediated by polyamidoamine dendrimer G2.5 and G3.5-In vitro and in vivo study. Int. J. Pharm. 2012, 436, 764-770. [CrossRef] [PubMed]

21. Santos, P.; Watkinson, A.C.; Hadgraft, J.; Lane, M.E. Application of microemulsions in dermal and transdermal drug delivery. Skin Pharmacol. Physiol. 2008, 21, 246-259. [CrossRef] [PubMed]

22. McClements, D.J. Nanoemulsions versus microemulsions: Clarification of critical differences. Soft Matter 2012, 8, 1719-1729. [CrossRef]

23. Anton, N.; Vandamme, T.F. Nano-emulsions and micro-emulsions: Clarifications of the critical differences. Pharm. Res. 2011, 28, 978-985. [CrossRef] [PubMed]

24. Gupta, A.; Eral, H.B.; Hatton, T.A.; Doyle, P.S. Nanoemulsions: Formation, properties and applications. Soft Matter 2016, 12, 2826-2841. [CrossRef] [PubMed]

25. Heuschkel, S.; Goebel, A.; Neubert, R.H. Microemulsions-Modern colloidal carrier for dermal and transdermal drug delivery. J. Pharm. Sci. 2008, 97, 603-631. [CrossRef] [PubMed]

26. Scriven, L.E. Equilibrium bicontinuous structure. Nature 1976, 263, 123-125. [CrossRef]

27. Lindman, B.; Shinoda, K.; Olsson, U.; Anderson, D.; Karlström, G.; Wennerström, H. On the demonstration of bicontinuous structures in microemulsions. Colloids Surf. A Physicochem. Eng. Asp. 1989, 38, 205-224. [CrossRef] 
28. Bhatia, G.; Zhou, Y.; Banga, A.K. Adapalene microemulsion for transfollicular drug delivery. J. Pharm. Sci. 2013, 102, 2622-2631. [CrossRef] [PubMed]

29. Naoui, W.; Bolzinger, M.A.; Fenet, B.; Pelletier, J.; Valour, J.P.; Kalfat, R.; Chevalier, Y. Microemulsion microstructure influences the skin delivery of an hydrophilic drug. Pharm. Res. 2011, 28, 1683-1695. [CrossRef] [PubMed]

30. Anton, N.; Benoit, J.P.; Saulnier, P. Design and production of nanoparticles formulated from nano-emulsion templates-a review. J. Control. Release 2008, 128, 185-199. [CrossRef] [PubMed]

31. Jasmina, H.; Džana, O.; Alisa, E.; Edina, V.; Ognjenka, R. Preparation of nanoemulsions by high-energy and low energy emulsification methods. In CMBEBIH 2017, Proceedings of the International Conference on Medical and Biological Engineering (IFMBE), Sarajevo, Bosnia and Herzegovina, 16-18 March 2017; Badnjevic, A., Ed.; Springer: Singapore, 2017.

32. Sole, I.; Solans, C.; Maestro, A.; Gonzalez, C.; Gutierrez, J.M. Study of nano-emulsion formation by dilution of microemulsions. J. Colloid Interface Sci. 2012, 376, 133-139. [CrossRef] [PubMed]

33. Wang, L.; Tabor, R.; Eastoe, J.; Li, X.; Heenan, R.K.; Dong, J. Formation and stability of nanoemulsions with mixed ionic-nonionic surfactants. Phys. Chem. Chem. Phys. 2009, 11, 9772-9778. [CrossRef] [PubMed]

34. Pons, R.; Carrera, I.; Caelles, J.; Rouch, J.; Panizza, P. Formation and properties of mini-emulsions formed by microemulsions dilution. Adv. Colloid Interface Sci. 2003, 106, 129-146. [CrossRef]

35. Vitale, S.A.; Katz, J.L. Liquid droplet dispersions formed by homogeneous liquid-Liquid nucleation: "The ouzo effect". Langmuir 2003, 19, 4105-4110. [CrossRef]

36. Wang, L.; Mutch, K.J.; Eastoe, J.; Heenan, R.K.; Dong, J. Nanoemulsions prepared by a two-step low-energy process. Langmuir 2008, 24, 6092-6099. [CrossRef] [PubMed]

37. Lee, H.S.; Morrison, E.D.; Frethem, C.D.; Zasadzinski, J.A.; McCormick, A.V. Cryogenic electron microscopy study of nanoemulsion formation from microemulsions. Langmuir 2014, 30, 10826-10833. [CrossRef] [PubMed]

38. Kreilgaard, M.; Pedersen, E.J.; Jaroszewski, J.W. NMR characterisation and transdermal drug delivery potential of microemulsion systems. J. Control. Release 2000, 69, 421-433. [CrossRef]

39. Paolino, D.; Ventura, C.A.; Nistico, S.; Puglisi, G.; Fresta, M. Lecithin microemulsions for the topical administration of ketoprofen: Percutaneous adsorption through human skin and in vivo human skin tolerability. Int. J. Pharm. 2002, 244, 21-31. [CrossRef]

40. Hua, L.; Weisan, P.; Jiayu, L.; Ying, Z. Preparation, evaluation, and NMR characterization of vinpocetine microemulsion for transdermal delivery. Drug Dev. Ind. Pharm. 2004, 30, 657-666. [CrossRef] [PubMed]

41. Lopes, L.B. Overcoming the Cutaneous Barrier with Microemulsions. Pharmaceutics 2014, 6, 52-77. [CrossRef] [PubMed]

42. Ita, K. Progress in the use of microemulsions for transdermal and dermal drug delivery. Pharm. Dev. Technol. 2017, 22, 467-475. [CrossRef] [PubMed]

43. Cavalcanti, A.L.; Reis, M.Y.; Silva, G.C.; Ramalho, I.M.; Guimaraes, G.P.; Silva, J.A.; Saraiva, K.L.; Damasceno, B.P. Microemulsion for topical application of pentoxifylline: In vitro release and in vivo evaluation. Int. J. Pharm. 2016, 506, 351-360. [CrossRef] [PubMed]

44. Danino, D.; Bernheim-Groswasser, A.; Talmon, Y. Digital cryogenic transmission electron microscopy: An advanced tool for direct imaging of complex fluids. Colloids Surf. A Physicochem. Eng. Asp. 2001, 183-185, 113-122. [CrossRef]

45. Podlogar, F.; Gasperlin, M.; Tomsic, M.; Jamnik, A.; Rogac, M.B. Structural characterisation of water-Tween 40/Imwitor 308-isopropyl myristate microemulsions using different experimental methods. Int. J. Pharm. 2004, 276, 115-128. [CrossRef] [PubMed]

46. Bhattacharya, S.; Stokes, J.P.; Kim, M.W.; Huang, J.S. Percolation in an oil-continuous microemulsion. Phys. Rev. Lett. 1985, 55, 1884-1887. [CrossRef] [PubMed]

47. Thevenin, M.A.; Grossiord, J.L.; Poelman, M.C. Sucrose esters/cosurfactant microemulsion systems for transdermal delivery: Assessment of bicontinuous structures. Int. J. Pharm. 1996, 137, 177-186. [CrossRef]

48. Lutz, R.; Aserin, A.; Wachtel, E.J.; Ben-Shoshan, E.; Danino, D.; Garti, N. A Study of the Emulsified Microemulsion by SAXS, Cryo-TEM, SD-NMR, and Electrical Conductivity. J. Dispers. Sci. Technol. 2007, 28, 1149-1157. [CrossRef]

49. Acharya, D.P.; Hartley, P.G. Progress in microemulsion characterization. Curr. Opin. Colloid Interface Sci. 2012, 17, 274-280. [CrossRef] 
50. Hoppel, M.; Juric, S.; Ettl, H.; Valenta, C. Effect of monoacyl phosphatidylcholine content on the formation of microemulsions and the dermal delivery of flufenamic acid. Int. J. Pharm. 2015, 479, 70-76. [CrossRef] [PubMed]

51. Lademann, J.; Richter, H.; Meinke, M.; Sterry, W.; Patzelt, A. Which skin model is the most appropriate for the investigation of topically applied substances into the hair follicles? Skin Pharmacol. Physiol. 2010, 23, 47-52. [CrossRef] [PubMed]

52. Yousef, S.; Liu, X.; Mostafa, A.; Mohammed, Y.; Grice, J.E.; Anissimov, Y.G.; Sakran, W.; Roberts, M.S. Estimating Maximal In Vitro Skin Permeation Flux from Studies Using Non-sink Receptor Phase Conditions. Pharm. Res. 2016, 33, 2180-2194. [CrossRef] [PubMed]

53. Baspinar, Y.; Borchert, H.H. Penetration and release studies of positively and negatively charged nanoemulsions-Is there a benefit of the positive charge? Int. J. Pharm. 2012, 430, 247-252. [CrossRef] [PubMed]

54. Baspinar, Y.; Keck, C.M.; Borchert, H.H. Development of a positively charged prednicarbate nanoemulsion. Int. J. Pharm. 2010, 383, 201-208. [CrossRef] [PubMed]

55. Lu, W.C.; Chiang, B.H.; Huang, D.W.; Li, P.H. Skin permeation of D-limonene-based nanoemulsions as a transdermal carrier prepared by ultrasonic emulsification. Ultrason. Sonochem. 2014, 21, 826-832. [CrossRef] [PubMed]

56. Campani, V.; Biondi, M.; Mayol, L.; Cilurzo, F.; Pitaro, M.; de Rosa, G. Development of nanoemulsions for topical delivery of vitamin K1. Int. J. Pharm. 2016, 511, 170-177. [CrossRef] [PubMed]

57. Dasgupta, S.; Dey, S.; Choudhury, S.; Mazumder, B. Topical delivery of aceclofenac as nanoemulsion comprising excipients having optimum emulsification capabilities: Preparation, characterization and in vivo evaluation. Exp. Opin. Drug Deliv. 2013, 10, 411-420. [CrossRef] [PubMed]

58. Hussain, A.; Samad, A.; Singh, S.K.; Ahsan, M.N.; Haque, M.W.; Faruk, A.; Ahmed, F.J. Nanoemulsion gel-based topical delivery of an antifungal drug: In vitro activity and in vivo evaluation. Drug Deliv. 2016, 23, 642-647. [CrossRef] [PubMed]

59. Teichmann, A.; Heuschkel, S.; Jacobi, U.; Presse, G.; Neubert, R.H.; Sterry, W.; Lademann, J. Comparison of stratum corneum penetration and localization of a lipophilic model drug applied in an o/w microemulsion and an amphiphilic cream. Eur. Pharm. Biopharm. 2007, 67, 699-706. [CrossRef] [PubMed]

60. Wosicka, H.; Cal, K. Targeting to the hair follicles: Current status and potential. J. Dermatol. Sci. 2010, 57, 83-89. [CrossRef] [PubMed]

61. Lademann, J.; Knorr, F.; Richter, H.; Blume-Peytavi, U.; Vogt, A.; Antoniou, C.; Sterry, W.; Patzelt, A. Hair follicles-An efficient storage and penetration pathway for topically applied substances. Summary of recent results obtained at the Center of Experimental and Applied Cutaneous Physiology, Charite-Universitatsmedizin Berlin, Germany. Skin Pharmacol. Physiol. 2008, 21, 150-155. [CrossRef] [PubMed]

62. Kweon, J.H.; Chi, S.C.; Park, E.S. Transdermal delivery of diclofenac using microemulsions. Arch. Pharm. Res. 2004, 27, 351-356. [CrossRef] [PubMed]

63. Hamed, R.; Basil, M.; AlBaraghthi, T.; Sunoqrot, S.; Tarawneh, O. Nanoemulsion-based gel formulation of diclofenac diethylamine: Design, optimization, rheological behavior and in vitro diffusion studies. Pharm. Dev. Technol. 2016, 21, 980-989. [CrossRef] [PubMed]

64. Lee, J.; Lee, Y.; Kim, J.; Yoon, M.; Choi, Y.W. Formulation of microemulsion systems for transdermal delivery of aceclofenac. Arch. Pharm. Res. 2005, 28, 1097-1102. [CrossRef] [PubMed]

65. Isailovic, T.; Ethordevic, S.; Markovic, B.; Randelovic, D.; Cekic, N.; Lukic, M.; Pantelic, I.; Daniels, R.; Savic, S. Biocompatible Nanoemulsions for Improved Aceclofenac Skin Delivery: Formulation Approach Using Combined Mixture-Process Experimental Design. J. Pharm. Sci. 2016, 105, 308-323. [CrossRef] [PubMed]

66. Park, E.S.; Cui, Y.; Yun, B.J.; Ko, I.J.; Chi, S.C. Transdermal delivery of piroxicam using microemulsions. Arch. Pharm. Res. 2005, 28, 243-248. [CrossRef] [PubMed]

67. Shakeel, F.; Ramadan, W.; Ahmed, M.A. Investigation of true nanoemulsions for transdermal potential of indomethacin: Characterization, rheological characteristics, and ex vivo skin permeation studies. J. Drug Target. 2009, 17, 435-441. [CrossRef] [PubMed]

68. Shakeel, F.; Ramadan, W.; Gargum, H.M.; Singh, R. Preparation and in vivo evaluation of indomethacin loaded true nanoemulsions. Sci. Pharm. 2010, 78, 47-56. [CrossRef] [PubMed] 
69. Ledet, G.; Pamujula, S.; Walker, V.; Simon, S.; Graves, R.; Mandal, T.K. Development and in vitro evaluation of a nanoemulsion for transcutaneous delivery. Drug Dev. Ind. Pharm. 2014, 40, 370-379. [CrossRef] [PubMed]

70. Subramanian, N.; Ghosal, S.K.; Moulik, S.P. Enhanced in vitro percutaneous absorption and in vivo anti-inflammatory effect of a selective cyclooxygenase inhibitor using microemulsion. Drug Dev. Ind. Pharm. 2005, 31, 405-416. [CrossRef] [PubMed]

71. Shakeel, F.; Baboota, S.; Ahuja, A.; Ali, J.; Shafiq, S. Enhanced anti-inflammatory effects of celecoxib from a transdermally applied nanoemulsion. Die Pharm. 2009, 64, 258-259.

72. Lala, R.R.; Awari, N.G. Nanoemulsion-based gel formulations of COX-2 inhibitors for enhanced efficacy in inflammatory conditions. Appl. Nanosci. 2014, 4, 143-151. [CrossRef]

73. Abd, E.; Namjoshi, S.; Mohammed, Y.H.; Roberts, M.S.; Grice, J.E. Synergistic Skin Penetration Enhancer and Nanoemulsion Formulations Promote the Human Epidermal Permeation of Caffeine and Naproxen. J. Pharm. Sci. 2016, 105, 212-220. [CrossRef] [PubMed]

74. Hoppel, M.; Ettl, H.; Holper, E.; Valenta, C. Influence of the composition of monoacyl phosphatidylcholine based microemulsions on the dermal delivery of flufenamic acid. Int. J. Pharm. 2014, 475, 156-162. [CrossRef] [PubMed]

75. Mahrhauser, D.S.; Kahlig, H.; Partyka-Jankowska, E.; Peterlik, H.; Binder, L.; Kwizda, K.; Valenta, C. Investigation of microemulsion microstructure and its impact on skin delivery of flufenamic acid. Int. J. Pharm. 2015, 490, 292-297. [CrossRef] [PubMed]

76. Rhee, Y.S.; Choi, J.G.; Park, E.S.; Chi, S.C. Transdermal delivery of ketoprofen using microemulsions. Int. J. Pharm. 2001, 228, 161-170. [CrossRef]

77. Kim, B.S.; Won, M.; Lee, K.M.; Kim, C.S. In vitro permeation studies of nanoemulsions containing ketoprofen as a model drug. Drug Deliv. 2008, 15, 465-469. [CrossRef] [PubMed]

78. Park, K.M.; Lee, M.K.; Hwang, K.J.; Kim, C.K. Phospholipid-based microemulsions of flurbiprofen by the spontaneous emulsification process. Int. J. Pharm. 1999, 183, 145-154. [CrossRef]

79. Dasgupta, S.; Ghosh, S.K.; Ray, S.; Kaurav, S.S.; Mazumder, B. In vitro \& in vivo studies on lornoxicam loaded nanoemulsion gels for topical application. Curr. Drug Deliv. 2014, 11, 132-138. [PubMed]

80. Khurana, S.; Jain, N.K.; Bedi, P.M. Nanoemulsion based gel for transdermal delivery of meloxicam: Physico-chemical, mechanistic investigation. Life Sci. 2013, 92, 383-392. [CrossRef] [PubMed]

81. Sintov, A.C.; Shapiro, L. New microemulsion vehicle facilitates percutaneous penetration in vitro and cutaneous drug bioavailability in vivo. J. Control. Release 2004, 95, 173-183. [CrossRef] [PubMed]

82. Duangjit, S.; Mehr, L.M.; Kumpugdee-Vollrath, M.; Ngawhirunpat, T. Role of simplex lattice statistical design in the formulation and optimization of microemulsions for transdermal delivery. Biol. Pharm. Bull. 2014, 37, 1948-1957. [CrossRef] [PubMed]

83. Mahrhauser, D.; Hoppel, M.; Scholl, J.; Binder, L.; Kahlig, H.; Valenta, C. Simultaneous analysis of skin penetration of surfactant and active drug from fluorosurfactant-based microemulsions. Eur. J. Pharm. Biopharm. 2014, 88, 34-39. [CrossRef] [PubMed]

84. Todosijevic, M.N.; Savic, M.M.; Batinic, B.B.; Markovic, B.D.; Gasperlin, M.; Randelovic, D.V.; Lukic, M.Z.; Savic, S.D. Biocompatible microemulsions of a model NSAID for skin delivery: A decisive role of surfactants in skin penetration/irritation profiles and pharmacokinetic performance. Int. J. Pharm. 2015, 496, 931-941. [CrossRef] [PubMed]

85. Kriwet, K.; Muller-Goyman, C.C. Diclofenac release from phospholipid drug systems and permeation through excised human stratum corneum. Int. J. Pharm. 1995, 135, 231-242. [CrossRef]

86. Dreher, F.; Walde, P.; Walther, P.; Wehrli, E. Interaction of a lecithin microemulsion gel with human stratum corneum and its effect on human stratum corneum transport. J. Control. Release 1997, 45, 131-140. [CrossRef]

87. Naeem, M.; Rahman, N.U.; Tavares, G.D.; Barbosa, S.F.; Chacra, N.B.; Lobenberg, R.; Sarfraz, M.K. Physicochemical, in vitro and in vivo evaluation of flurbiprofen microemulsion. An. Acad. Bras. Cienc. 2015, 87, 1823-1831. [CrossRef] [PubMed]

88. Kantarci, G.; Ozguney, I.; Karasulu, H.Y.; Guneri, T.; Basdemir, G. In vitro permeation of diclofenac sodium from novel microemulsion formulations through rabbit skin. Drug Dev. Res. 2005, 65, 17-25. [CrossRef]

89. Sintov, A.C.; Botner, S. Transdermal drug delivery using microemulsion and aqueous systems: Influence of skin storage conditions on the in vitro permeability of diclofenac from aqueous vehicle systems. Int. J. Pharm. 2006, 311, 55-62. [CrossRef] [PubMed] 
90. El-Leithy, E.S.; Ibrahim, H.K.; Sorour, R.M. In vitro and in vivo evaluation of indomethacin nanoemulsion as a transdermal delivery system. Drug Deliv. 2015, 22, 1010-1017. [CrossRef] [PubMed]

91. Klang, V.; Matsko, N.; Raupach, K.; El-Hagin, N.; Valenta, C. Development of sucrose stearate-based nanoemulsions and optimisation through gamma-cyclodextrin. Eur. J. Pharm. Biopharm. 2011, 79, 58-67. [CrossRef] [PubMed]

92. Hussain, A.; Samad, A.; Nazish, I.; Ahmed, F.J. Nanocarrier-based topical drug delivery for an antifungal drug. Drug Dev. Ind. Pharm. 2014, 40, 527-541. [CrossRef] [PubMed]

93. Zheng, Y.; Ouyang, W.Q.; Wei, Y.P.; Syed, S.F.; Hao, C.S.; Wang, B.Z.; Shang, Y.H. Effects of Carbopol(R) 934 proportion on nanoemulsion gel for topical and transdermal drug delivery: A skin permeation study. Int. J. Nanomed. 2016, 11, 5971-5987. [CrossRef] [PubMed]

94. Klang, V.; Haberfeld, S.; Hartl, A.; Valenta, C. Effect of gamma-cyclodextrin on the in vitro skin permeation of a steroidal drug from nanoemulsions: Impact of experimental setup. Int. J. Pharm. 2012, 423, 535-542. [CrossRef] [PubMed]

95. Hoeller, S.; Sperger, A.; Valenta, C. Lecithin based nanoemulsions: A comparative study of the influence of non-ionic surfactants and the cationic phytosphingosine on physicochemical behaviour and skin permeation. Int. J. Pharm. 2009, 370, 181-186. [CrossRef] [PubMed]

96. Kong, M.; Chen, X.G.; Kweon, D.K.; Park, H.J. Investigations on skin permeation of hyaluronic acid based nanoemulsion as transdermal carrier. Carbohydr. Polym. 2011, 86, 837-843. [CrossRef]

97. Kumar, D.; Ali, J.; Baboota, S. Omega 3 fatty acid-enriched nanoemulsion of thiocolchicoside for transdermal delivery: Formulation, characterization and absorption studies. Drug Deliv. 2016, 23, 591-600. [CrossRef] [PubMed]

98. Zheng, W.W.; Zhao, L.; Wei, Y.M.; Ye, Y.; Xiao, S.H. Preparation and the in vitro evaluation of nanoemulsion system for the transdermal delivery of granisetron hydrochloride. Chem. Pharm. Bull. 2010, 58, 1015-1019. [CrossRef] [PubMed]

(C) 2017 by the authors. Licensee MDPI, Basel, Switzerland. This article is an open access article distributed under the terms and conditions of the Creative Commons Attribution (CC BY) license (http:/ / creativecommons.org/licenses/by/4.0/). 